\title{
1 Spatial distribution of thermokarst terrain in Arctic Alaska
}

2

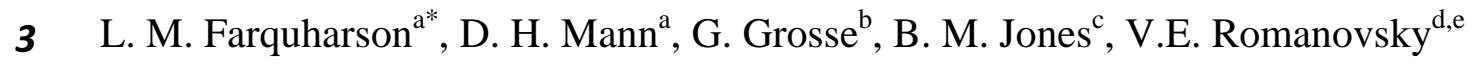

4

$5 \quad{ }^{a}$ Department of Geosciences, University of Alaska Fairbanks, Fairbanks, Alaska, USA

$6{ }^{\mathrm{b}}$ Alfred Wegener Institute Helmholtz Centre for Polar and Marine Research, Potsdam, Germany

$7 \quad{ }^{c}$ U.S. Geological Survey, Alaska Science Center, Anchorage, Alaska, USA

$8{ }^{\mathrm{d}}$ Geophysical Institute, University of Alaska Fairbanks, Fairbanks, Alaska, USA

$9 \quad{ }^{\mathrm{e}}$ Tyumen State Oil and Gas University, Tyumen, Tyument Oblast 625000, Russia

10

11

$12 *$ Corresponding author. Email address: lmfarquharson@alaska.edu (L. Farquharson).

13

\section{Abstract}

15 In landscapes underlain by ice-rich permafrost, the development of thermokarst landforms can have 16 drastic impacts on ecosystem processes and human infrastructure. Here we describe the distribution

17 of thermokarst landforms in the continuous permafrost zone of Arctic Alaska, analyze linkages to the

18 underlying surficial geology, and discuss the vulnerability of different types of landscapes to future

19 thaw. We identified nine major thermokarst landforms and then mapped their distributions in twelve

20 representative study areas totaling $300-\mathrm{km}^{2}$. These study areas differ in their geologic history,

21 permafrost-ice content, and ground thermal regime. Results show that $63 \%$ of the entire study area is

22 occupied by thermokarst landforms and that the distribution of thermokarst landforms and overall

23 landscape complexity varies markedly with surficial geology. Areas underlain by ice-rich marine silt

24 are the most affected by thermokarst (97\% of total area), whereas areas underlain by glacial drift are

25 least affected (14\%). Drained thermokarst-lake basins are the most widespread thermokarst

26 landforms, covering 33\% of the entire study region, with greater prevalence in areas of marine silt

27 (48\% coverage), marine sand (47\%), and aeolian silt (34\%). Thermokarst-lakes are the second most

28 common thermokarst landform, covering $16 \%$ of the study region, with highest coverage in areas

29 underlain by marine silt (39\% coverage). Thermokarst troughs and pits cover $7 \%$ of the study region

30 and are the third most prevalent thermokarst landform. They are most common in areas underlain by 
31 deltaic sands and gravels (18\% coverage) and marine sand (12\%). Alas valleys are widespread in

32 areas of aeolian silt (14\%) located in gradually sloping uplands. Areas of marine silt have been

33 particularly vulnerable to thaw in the past because they are ice-rich and have low-gradient topography

34 facilitating the repeated development of thermokarst-lakes. In the future, ice-rich aeolian, upland

35 terrain (yedoma) will be particularly susceptible to thaw because it still contains massive

36 concentrations of ground ice in the form of syngenetic ice-wedges that have remained largely intact

37 since the Pleistocene.

38

39 Keywords: thermokarst; thaw; Arctic; landform mapping

40

41

1. Introduction

42 Over the past 14,000 years of post-glacial times, one of the main geomorphic processes operating

43 in Arctic lowlands has been the thaw of ice-rich permafrost leading to the formation of

44 thermokarst topography (Czudek and Demek, 1970; Burn, 1992; Jorgenson et al. 2008a; Grosse

45 et al., 2013). Thermokarst, defined as surface subsidence caused by the melting of massive ice

46 (van Everdingen, 2005), can have pervasive effects on hydrological and ecological processes

47 (Kokelj et al., 2005; Myers-Smith et al., 2007), including the carbon cycle (Grosse et al., 2011).

48 In addition to thermokarst, other thaw-related processes include thermo-erosion (thermal and

49 mechanical erosion by water), thermo-denudation (thaw of sediment subaerially and its

50 subsequent transport by gravity), and thermo-abrasion (the thaw and transport of material by

51 wave action; Are, 1978; Washburn, 1979; van Everdingen, 2005). Here the term thermokarst,

52 refers to the topography and landforms developed after the melting of ground ice by any of the

53 aforementioned processes.

54 In Arctic Alaska, the region north of the Brooks Range underlain by continuous

55 permafrost (Fig. 1), lowland substrates are commonly ice rich, with total volumetric ice contents

56 ranging from 40 to $90 \%$ (Kanevskiy et al., 2013). These high ice contents make the ground

57 vulnerable to thermal disturbance and development of thermokarst terrain. These landforms are

58 diverse: 23 different types have been identified based on topography and hydrology in Arctic

59 Alaska alone (Jorgenson et al. 2008a; Jorgenson, 2013; Kokelj and Jorgenson, 2013).

60 A number of previous studies have mapped the spatial distribution of thermokarst

61 landforms in arctic lowlands. In Canada, these include thermokarst-lakes (Côté and Burn, 2002; 
62 Olthof et al., 2015), active-layer detachment slides (Lewkowicz and Harris, 2005; Lamoureux

63 and Lafreniére, 2009), retrogressive thaw slumps (Lantuit and Pollard, 2008; Lantz and Kokelj,

64 2008; Kokelj et al., 2009), and degrading ice-wedges (Steedman et al., 2016). In Alaska (Table

65 2), mapping has focused mainly on the spatial distribution of thermokarst-lakes and drained

66 thermokarst-lake basins (Frohn et al., 2005; Hinkel et al., 2005; Jones et al., 2011; Jones and

67 Arp, 2015) and to a lesser extent beaded streams (Arp et al., 2015), retrogressive thaw slumps

68 (Balser et al., 2014), and ponds formed by degrading ice-wedges (Raynolds et al., 2014;

69 Jorgenson et al. 2015; Liljedahl et al., 2016). In Siberia, Veremeeva and Gubin, (2009) identified

70 a number of landscape typologies in the Kolyma River lowlands including upland yedoma and

71 alases. Other mapping in Siberia has quantified thermokarst-lake and drained thermokarst-lake

72 basin distribution in yedoma regions (Grosse et al. 2008; Morgenstern et al. 2011).

73 The combination of ice-rich permafrost and a rapidly warming climate makes Arctic

74 Alaska an interesting and topical place to study the geomorphic patterns and processes of

75 thermokarst development. Mean annual air temperature (MAAT) at Point Barrow has increased

76 by $\sim 3^{\circ} \mathrm{C}$ since 1950 (Wendler et al., 2010), and borehole measurements of ground temperatures

77 indicate permafrost has warmed as much as $4^{\circ} \mathrm{C}$ across the region during recent decades

78 (Romanovsky et al. 2010; Romanovsky et al. 2015; Smith et al., 2010). Warming over the

79 coming century is expected to be the greatest at high latitudes (Cohen et al., 2014), and MAAT

80 in the Arctic is projected to rise as much as $8.3^{\circ} \mathrm{C}$ (IPCC, 2013).

$81 \quad$ Ongoing warming has already led to a noticeable increase in thermokarst development in

82 some parts of Arctic Alaska (Jorgenson et al., 2006; Raynolds et al., 2014; Jorgenson et al. 2015;

83 Liljedahl et al., 2016), and we know from paleorecords that warming climate can trigger rapid

84 and widespread thawing of permafrost (Mann et al., 2010; Gaglioti et al., 2014). Short-lived

85 ecological disturbances in conjunction with longer-term warming trends can also trigger

86 thermokarst. For example, wildfires are projected to increase in frequency, intensity, and extent

87 in Arctic Alaska as climate warms there (Hu et al., 2015). Burning removes the organic mat that

88 insulates the ground and buffers the permafrost from warming surface conditions (Jones et al.,

89 2015).

90 To predict landscape-scale responses to ongoing climatic warming in the Arctic, we need

91 to better understand what factors control thermokarst development there. With this goal in mind,

92 we use remotely sensed imagery to map thermokarst landforms and quantitatively characterize 
93 how geological substrate and topography interact with the content and structure of ground ice to

94 determine the incidence, morphology, and distribution of thermokarst landforms that have

95 developed in Arctic Alaska in post-glacial times. Our results provide a basis for predicting how

96 thaw-related, geomorphic processes may respond to climate warming during the coming century.

97

$98 \quad 2$. Study region

99 Our 12 study areas are located on the Arctic Coastal Plain, in the Arctic Foothills, and in the

100 Brooks Range (Wahrhaftig, 1965; Fig. 1). We selected these study areas to be representative 101 examples of the landscapes within which they occur. The number of study areas per type of

102 surficial geology corresponds roughly to how widely this geological substrate is distributed in

103 the study region (Fig. 1, Table 1). Detailed mapping was conducted in six types of surficial

104 geologies: aeolian silt, aeolian sand, marine silt, marine sand, glacial drift, and deltaic sand and

105 gravel (Jorgenson et al., 2008b). All of the study areas are underlain by continuous permafrost

106 (Fig. 2). All sites except those in the Brooks Range are in areas that remained unglaciated during

107 the last glacial maximum (ca. 21,000 YBP (years before present). The permafrost temperature

108 data (for the period 1999 to 2011) used in this study were obtained from the U.S. Geological

109 Survey (http://pubs.usgs.gov/ds/812/introduction.html) and the University of Alaska Geophysical

110 Institute Permafrost Laboratory (Romanovsky et al., unpublished data; Fig. 2, Table A.2).

111 Permafrost temperature stations (shown in Fig. 1) do not coincide directly with our study areas

112 but are located within the same surficial geology units. Mean annual (calendar year) values for

113 ground temperature are calculated using mean daily data from each site.

114

115 2.1. Arctic Coastal Plain: Deltaic sands and gravels

116 Deltaic sands and gravels cover $2 \%$ of the study region (Fig. 1, Table 1). Representative of these 117 deposits, study area A (Fig. 1) is located on the Ikpikpuk River delta where the surficial geology

118 is characterized by fine-grained, overbank deposits along with two types of channel deposits:

119 sandy riverbed and lateral-accretion deposits (Shur and Jorgenson, 1998). The mean slope of the 120 ground surface on the Ikpikpuk Delta is $0.04^{\circ}$ (Table 1, all slope values represent regional mean

121 slope, see section 3.2). Once delta channels are abandoned, epigenetic and syngenetic permafrost 122 aggrades and ice-wedge polygons form. Total volumetric ice contents in these deposits vary 123 widely but average $70 \%$ in areas of syngenetic ice-wedges (Shur and Jorgenson, 1998). The 
124 Ikpikpuk delta probably dates to the mid-Holocene when relative sea level stabilized. Most of the

125 delta surface is either barren or vegetated by pioneering herbaceous vegetation such as Salix

126 alaxensis, Salix lanata, and Carex aquatilis (Jorgenson et al., 1998). No permafrost temperature

127 data are available for this surficial geology type.

128

129 2.2. Arctic Coastal Plain: marine silt

130 Study area B (Fig. 1) is situated on marine silt, which was deposited during the most recent

131 marine transgression affecting the Arctic Coastal Plain during the Simpsonian interstadial ca.

$13275,000 \mathrm{cal}$. YBP when relative sea level was $\sim 7 \mathrm{~m}$ higher than today (Dinter et al., 1990).

133 Marine silt covers $4 \%$ of the overall study region (Fig. 1) and is limited to outer portions of the

134 Arctic Coastal Plain. The land surface here is basically flat with a mean slope of only $0.03^{\circ}$

135 (Table 1). At Drew Point (Fig. 2), permafrost temperatures at $1.2 \mathrm{~m}$ depth averaged $-8.0^{\circ} \mathrm{C}$

136 between 1999 and 2010 and have increased by $0.6^{\circ} \mathrm{C}$ over this period. At marine-silt sites, total

137 volumetric ice content reaches 86\% (Kanevskiy et al., 2013), and vegetation is moist acidic

138 tundra composed of wetland sedges, Carex aquatilis and Eriophorum angustifolium, and mosses,

139 Drepanocladus brevifolius, and Limprichtia revolvens (Raynolds et al., 2006).

140

141 2.3. Arctic Coastal Plain: marine sand

142 Study areas C, D, E, and F are located in areas underlain by marine sand (Fig. 1). In total, marine

143 sand underlies $33 \%$ of the study region, and these areas have a mean slope of $0.10^{\circ}$ (Table 1 ).

144 This sand was deposited during multiple marine transgressions of Pleistocene and Pliocene age

145 (Dinter et al., 1990). Permafrost temperatures at $1.2 \mathrm{~m}$ depth averaged $-7.3^{\circ} \mathrm{C}$ between 1999 and

1462010 and increased by $0.8^{\circ} \mathrm{C}$ during this period (Fig. 2, Fish Creek and South Meade sites). At

147 the marine-sand sites, total volumetric ice content averages 80\% (Kanevskiy et al., 2013), and

148 vegetation is moist acidic tundra composed of wetland sedge, Carex aquatilis and Eriophorum

149 angustifolium, mosses, Drepanocladus spp. and Sphagnum spp., and dwarf shrubs, Dryas

150 integrifolia and Salix reticulata (Raynolds et al., 2006).

151

152 2.4. Arctic Coastal Plain: aeolian sand

153 The aeolian sand sites (G, H, and I; Fig. 1) are located along the southern margin of the Arctic

154 Coastal Plain in the area of the now stabilized Ikpikpuk Sand Sea (Carter, 1981; Galloway and 
155 Carter, 1993). Here late Pleistocene and early Holocene deposits of aeolian sand reach up to 30

$156 \mathrm{~m}$ in thickness. The former Ikpikpuk Sand Sea is characterized by stabilized longitudinal and

157 parabolic sand dunes covering $>15,000-\mathrm{km}^{2}$ of the Arctic Coastal Plain. The last period of

158 widespread aeolian activity was 8000-11,000 cal. YBP (Carter, 1981; Dinter et al., 1990). Since

159 this time, reactivation has occurred only intermittently and locally. Altogether, aeolian sand 160 covers $23 \%$ of the study region (Fig. 1, Table 1), and the mean slope of the area blanketed by 161 aeolian sand is $0.10^{\circ}$ (Table 1). Mean permafrost temperatures at $1.2 \mathrm{~m}$ depth in the former sand 162 sea were $-5.9^{\circ} \mathrm{C}$ between 1999 and 2010, and they increased $0.8^{\circ} \mathrm{C}$ during this period (Fig. 2, 163 site Inigok). The average volumetric ice content here reaches 43\% (Kanevskiy et al., 2013),

164 which is slightly greater than the typical porosity of frozen sands. At aeolian sand sites,

165 vegetation cover is primarily moist, nonacidic tundra composed of sedge: Eriophorum

166 vaginatum, dwarf shrubs, Ledum palustre, Vaccinium vitis-idaea, Cassiope tetragona, and Rubus

167 chamaemorus, and mosses, Sphagnum compactum, Aulacomnium turgidum, and usually lacks

168 any peat accumulation (Raynolds et al., 2006).

169

170 2.5. Arctic Foothills: aeolian silt (yedoma)

171 Study areas $\mathrm{J}$ and $\mathrm{K}$ are located in a belt of ice-rich silt (yedoma) lying along the southern margin

172 of the Ikpikpuk Sand Sea and north of previously glaciated terrain (Fig. 1; Shur et al., 2012).

173 Yedoma is organic-rich silt (loess) deposited during the late Pleistocene. It typically contains

174 large, syngenetic ice-wedges (Kanevskiy et al., 2011). In total, yedoma covers 35\% of the study

175 region (Fig. 1), and the mean slope of the yedoma zone is $0.32^{\circ}$ (Table 1). Mean permafrost

176 temperatures at $1.2 \mathrm{~m}$ depth were $-5.2^{\circ} \mathrm{C}$ between 1999 and 2010 , and permafrost temperature

177 increased by as much as $1.0^{\circ} \mathrm{C}$ during this period (Fig. 2, sites Koluktak and Umiat). Deposition

178 of yedoma mainly took place during the late Pleistocene, and it accumulated up to $50 \mathrm{~m}$ thick in

179 some areas of Beringia (Schirrmeister et al., 2013). Within our study area, yedoma is

180 characterized by a high total volumetric ice content of $89 \%$, mainly because of the presence of

181 syngenetic ice-wedges (Kanevskiy et al., 2011). Vegetation cover is moist acidic tundra

182 characterized by sedges, Carex bigelowii, and Eriophorum angustifolium, dwarf shrubs, Dryas

183 integrifolia and Salix reticulata, forbes, Tephroseris frigida, and Eutrema edwardsii, and mosses,

184 Drepanocladus brevifolius and Distichium capillaceum (Raynolds et al., 2006). 


\subsection{Brooks Range: glacial drift}

Study area L is located in the Brooks Range where four glacial advances, the most recent between 24,000 and 17,000 cal. yr BP, have left behind a complex surficial geology (Hamilton, 2003; Fig. 1). In total, glacial drift covers $2 \%$ of the study region (Fig. 1), and these areas have a mean slope of $2.04^{\circ}$ (Table 1). Permafrost temperatures at $1.0 \mathrm{~m}$ depth are the warmest of all the surficial geology types, averaging $-4.6^{\circ} \mathrm{C}$ for the period 2000 to 2011 (Fig. 2, Galbraith). These ground temperatures increased by $1.5^{\circ} \mathrm{C}$ between 2000 and 2011 . Thermokarst landforms in this area have developed mainly from the melting of buried glacial ice bodies (Hamilton, 2003), augmented by the melting of Holocene-aged ice wedges. Thermokarst-lakes within this substrate type can also be termed kettle lakes in cases where they formed from the thaw and collapse of buried glacial ice. Vegetation is nonacidic tundra composed of sedges, Eriophorum vaginatum and Carex bigelowii, dwarf shrubs, Betula nana; Ledum palustre, Vaccinium vitis-idaea, and mosses, Sphagnum spp., and Hylocomium splendens (Reynolds et al. 2006).

\section{Methods}

\subsection{Definition of thermokarst landforms}

We selected study areas of contrasting surficial geology and ground-ice content based on the mapping of Jorgenson et al. (2008b). The study areas are representative of the terrain and surficial geology types occurring in Arctic Alaska.

We mapped nine different thermokarst landforms, all of which are familiar in the periglacial literature (French, 2007; Jorgenson, 2013; Soloviev, 1973), with the exception of flooded ice-wedge polygons and thaw valleys. The landforms in this study are not the only ones existing in Arctic Alaska, but they are the main ones. Five of the thermokarst landforms are large features $\left(>50 \mathrm{~m}^{2}\right)$ : thermokarst-lakes, drained thermokarst-lake basins, alas valleys (Soloviev, 1973; Goudie, 2004), thaw valleys, and retrogressive thaw slumps. Four of the thermokarst landforms are relatively small features $\left(<50 \mathrm{~m}^{2}\right)$ : beaded stream ponds, drained thaw-ponds, thermokarst troughs and pits, and flooded ice-wedge polygons (Fig. 3). Most thermokarst landforms were identified according to the visual characteristics and spatial dimensions described by Jorgenson et al. (2008a) and Jorgenson (2013). Drained thaw-ponds were identified aerially and during field surveys on the basis of pools of standing water, drowned vegetation, and concentric vegetation zonation suggesting variable water levels in the past. We used the 
217 descriptions of Soloviev (1973) to identify alas and thaw valleys. We classify alas and thaw

218 valleys together, as they exhibit the same morphology — thermokarst-lake basins connected by

219 valleys or valley-like features - but the term "alas valley" specifically refers to yedoma regions.

220

221

222

223

224

225

226

227

228

229

230

231

232

233

234

235

236

237

238

239

240

241

242

243

244

245

246

\subsection{Mapping of thermokarst landforms}

Thermokarst landforms (Fig. 3) were mapped in twelve $25-\mathrm{km}^{2}$ study areas (Figs. 1, 4). We delineated landforms by manually digitizing features using 2.5-m resolution, false color, infrared, aerial-image orthophotography (July, August, 2002-2006) for all sites except L, for which we used 0.3-m resolution World View 2 imagery. An IfSAR DSM (Inferometic Synthetic Aperture Radar Digital Surface Model) was also used for all sites. Raw IfSAR data were collected by Intermap Technologies using a STAR-3i airborne synthetic aperture radar system (high-resolution, single pass) in summers between 2002 and 2006 (Intermap, 2010). IfSAR DSM tiles were used to create a raster mosaic of the study areas with a horizontal resolution of $5 \mathrm{~m}$ and a vertical resolution of $1 \mathrm{~m}$. Bluff heights were calculated using the IfSAR DSM. Elevation ranges were assessed for individual landforms within a 50-m buffer around the feature. Slope data were calculated using the Scenarios Network for Alaska (SNAP) 1-km resolution Alaska slope model (http://ckan.snap.uaf.edu/dataset/slope). To estimate slope angles, we used 1-km resolution slope data, because the 5-m resolution, IfSAR slope data are affected by small-scale topographic features. For water bodies, we used the water and lake/river ice classes used in the National Land Cover Database (Homer et al., 2015), which is based on classification of 20012011 Landsat-5 Thematic Mapper data at 30-m resolution, which allows us to map all lakes $>1$ ha. Landforms were manually digitized in ArcMap v.10.0 (ESRI ${ }^{\mathrm{TM}}$ ) software (see Grosse et al., 2006; Morgenstern et al., 2011) at a scale of 1:2000. Landform metrics data were also calculated using ArcMap. To assess the accuracy of landform mapping, we conducted ground surveys of all 12 study areas in the summer of 2013. Qualitative surveys were conducted on foot, using maps overlain by our landform classification. In addition, all five authors have spent considerable time in the area, conducting geomorphic research, on foot and during low-elevation flight surveys.

We adhered to set rules when mapping complicated landforms. For instance, landform boundaries were manually delineated around clusters of thermokarst troughs and pits and flooded polygons exhibiting similar degradation and ponding characteristics. Beaded streams were digitized as polylines and then buffered with a width of $90 \mathrm{~m}$ (Arp et al., 2015) using the buffer 
247 analysis tool in ArcGIS. Multi-basin lakes and drained-lake basins were divided into individual

248 lakes when the basins exhibited roughly an hourglass shape indicative of coalescence. In site A

249 (Ikpikpuk Delta), active river channels were masked at the water line and not included in land-

250 cover calculations. Landform density was calculated by counting the number of each landform

251 type present in each study area, then dividing by the area affected by thermokarst.

252

2533.3 Classification of terrain as 'currently active thermokarst' or 'previously active thermokarst'

254 We used the spectral characteristics of vegetation cover and liquid water to classify thermokarst 255 landforms as either currently active or previously active. In addition, we mapped areas that had

256 no observable thermokarst landforms. Currently thermokarst affected landforms are those under

257 the influence of thermokarst processes at the time of image acquisition. In the case of

258 thermokarst trough and pit zones and thermokarst-lakes, we interpreted the presence of standing

259 water pits and troughs as indicative of active thermokarst, which may lead to underestimating the

260 extent of these features in areas with good drainage. In the case of beaded channels, we

261 interpreted the presence of water as a probable indicator of talik (thaw bulb) presence. All alas

262 and thaw valleys had low reflectivity values associated with landscape wetting and/or showed

263 signs of strong ice-wedge degradation and ponding at the head of the channel system.

264 Currently inactive landforms are those not actively developing at the time of image

265 acquisition. Vegetation cover was used as a key indicator of geomorphic stability. Vegetated

266 retrogressive thaw slump scars were classified as currently inactive thermokarst terrain. Areas

267 classified as non-thermokarst-affected were those where no evidence of either current or past 268 thermokarst activity was detected.

269 We quantified the extent of repeated ice aggradation and subsequent thaw across the

270 landscape by determining the number of overlapping generations of thermokarst-lakes (Billings

271 and Peterson, 1980; Jones et al., 2012). We mapped the cross-cutting relationships of multiple

272 thermokarst-lakes using the outlines of former basins where they were visible and extrapolating

273 the likely location of lake margins that had been destroyed by subsequent lake generations. To

274 make such extrapolations, we assume these lakes tend to have circular or elliptical shapes.

275

\section{4. Results}

277 4.1. Distribution of thermokarst landforms in relation to surficial geology 


\subsubsection{Deltaic sands and gravels}

279 On the Ikpikpuk delta (site A), 37\% of the landscape has been affected by thermokarst processes 280 (Figs. 4, 5, 6, Table 3). The most widely distributed landforms are thermokarst troughs and pits, 281 which cover $18 \%$ of the total area (Fig. 5, Table 3). Individual groupings of thermokarst troughs

282

283

284 285 286

\section{7} 288

289 290 291

292

293

294

295

296

297

298

299

300

301

302

303

304

305

306

307

308 and pits have an average area of 3.7 ha (Table 4). Small lakes (mean area 8.1 ha; Table 4) cover $13 \%$ of the study area. Mean elevation range is $4.7 \mathrm{~m}$ (Table 4). This study area has a landform density of 14.5 landforms per $\mathrm{km}^{2}$ (Fig. 7). No drained thermokarst-lake basins were observed, and all thermokarst landforms observed are currently classified as active (Fig. 6).

\subsubsection{Areas of marine silt}

The extent of thaw-affected terrain is greatest on the northern Arctic Coastal Plain where ice-rich marine silt is present (site B). Here, thermokarst has modified 97\% of the landscape (Figs. 4 and 6 , Table 3). Three percent of the area was unclassified because of the presence of small water bodies less than 1 ha in size situated within drained thermokarst-lake basins. Drained thermokarst-lake basins and thermokarst-lakes are the dominant thermokarst landforms, covering 48 and 39\% respectively of the study area (Fig. 5, Table 3). These basins and lakes have mean surface areas of 232 and 110 ha, respectively (Table 4). Mean bluff height is relatively low for thermokarst-lakes and drained thermokarst-lake basins, only 3.5 and $5.3 \mathrm{~m}$, respectively (Table 4). Up to four generations of drained-lake basins are present in addition to existing thermokarstlakes (Fig. 8). In this study area, a single zone of thermokarst troughs and pits is perched on an upland area comprising $9 \%$ of the total study area. Four types of thermokarst landforms are present, which yields a relatively low landform density of 0.9 per $\mathrm{km}^{2}$ (Fig. 7). A low landform density combined with a high percentage of thermokarst cover results from few landforms that are relatively large in size. When grouped into currently and previously active landforms, $48 \%$ of study area B is comprised of previously active landforms and $48 \%$ by currently active landforms (Fig. 6).

\subsubsection{Areas of marine sand}

Thermokarst processes affect $81 \%$ of study areas underlain by marine sand (sites C, D, E, F, Figs. 4, 5, 6, Table 3). Drained thermokarst-lake basins cover $47 \%$ of the total area, which is similar to their coverage of the marine silt sites (site B, Fig. 4, Table 3). Thermokarst-lakes and 
309 drained thermokarst-lake basins have a mean surface area of 33 and 59 ha, respectively (Table

310 4). Mean bluff heights for drained thermokarst-lake basins and thermokarst-lakes are 5.0 and 2.5

$311 \mathrm{~m}$, respectively. Up to five generations of drained thermokarst-lake basins are present in addition

312 to the existing thermokarst-lakes (Fig. 8). Thermokarst-lakes are less prevalent than drained

313 thermokarst-lake basins, covering only $18 \%$ of the total study area, whereas ice-wedge polygon

314 zones account for $12 \%$ of the combined marine sand sites (Fig. 5, Table 3). Other landforms

315 include alas valleys (3\%), drained thaw-ponds (0.2\%), and beaded streams (<1\%; Figs. 4 and 5).

316 Once grouped into currently and previously active landforms, 33\% of the land surface is

317 currently active, and $48 \%$ of the landscape by previously active landforms (Fig. 6). Marine sand

318 exhibits a high diversity of landform, with six types of thermokarst landforms present, including

319 drained thaw-ponds, beaded streams, and thaw valleys, resulting in an average of 5.9 individual

320 landforms per $\mathrm{km}^{2}$ (Fig. 7).

322 4.1.4. Aeolian sand

323 Thermokarst processes affect $50 \%$ of study areas located within the former Ikpikpuk Sand Sea

324 (sites G, H, I, Figs. 4, 5, and 6, Table 3). The most common landforms are thermokarst-lakes

$325(28 \%)$ and drained thermokarst-lake basins (16\%). Whereas previous studies (Jorgenson and

326 Shur, 2007) suggest non-thermokarst causes of lake initiation, our observations suggest that ice-

327 wedge degradation is an important mechanism in the growth of lakes in the former sand sea.

328 Areas of aeolian sand, as well as areas of marine sand, have the most diverse

329 geomorphology of any area mapped. In addition to thermokarst-lakes and drained thermokarst-

330 lake basins, four other thermokarst landforms occur: thermokarst troughs and pits, beaded

331 streams, thaw valleys, and drained thaw-ponds. Thermokarst-lakes and drained thermokarst-lake

332 basins cover areas of 38 and 37 ha, respectively (Table 4). The average height of lake bluffs

333 bordering drained thermokarst-lake basins is 7.0 and $9.0 \mathrm{~m}$. Only one generation of drained

334 thermokarst-lake basins occurs in addition to the existing thermokarst-lakes (Fig. 8). Zones of

335 thermokarst troughs and pits cover 5\% of aeolian sand areas (Table 3). Beaded streams, thaw

336 valleys, and drained thaw-ponds have similarly limited coverage. In total, 33\% of aeolian sand

337 areas are covered by currently active landforms and 17\% by previously active landforms (Fig. 6).

338 This leaves some $49 \%$ of the landscape that preserves relict, sand-dune landforms and so exhibits

339 no evidence of either past thermokarst processes or ongoing thermokarst activity (Fig. 6). 
4.1.5. Areas of aeolian silt

342 Thermokarst processes have affected 58\% of the landscape in the aeolian silt (yedoma) zone of

343 the Arctic Foothills (sites J and K, Figs. 4, 5, and 6, Table 3). Drained thermokarst-lake basins

344 are the most widely distributed landform (Fig. 5), covering $34 \%$ of the combined study areas

345 (Table 3) with a mean area of 80 ha per individual basin (Table 4). Mean bluff height bordering

346 drained thermokarst-lake basins and thermokarst-lakes is 19.3 and $11.0 \mathrm{~m}$, respectively. Some

$34724 \%$ of the landscape is characterized by currently active landforms and $34 \%$ by previously

348 active landforms (Fig. 6). Thermokarst trough and pit zones and beaded streams cover 4 and

$349<1 \%$ of the total area, respectively. Zones of aeolian silt show similar landform density to those

350 of glacial drift, with 22 landforms per thaw-affected $\mathrm{km}^{2}$ (Fig. 7). Up to three generations of

351 drained thermokarst-lake basins occur in addition to extant thermokarst-lakes (Fig. 8).

352 Thermokarst-lakes have a more restricted coverage here than do alas valleys, covering 6 and

$35314 \%$ of sites $\mathrm{J}$ and $\mathrm{K}$, respectively (Table 3). Individual alas valleys and thermokarst-lakes have a 354 mean area of 12 ha (Table 4).

355

\section{4.1.6. Glacial drift}

357 Areas underlain by glacial drift exhibit the lowest percent coverage by thermokarst landforms of 358 any study area, only $14 \%$ (site L, Figs. 4, 5, and 6, Table 3). Within the glacial drift, thermokarst359 lakes are the dominant thermokarst landform (Fig. 5), covering 12.6\%, with a mean area of 9 ha $360 \quad(\mathrm{n}=35$; Table 4). The average bluff height around these lakes is $13.7 \mathrm{~m}$, likely reflecting the 361 presence of massive, buried glacial ice in the area. Thaw slumps (observed only on lake margins; $362 \mathrm{n}=2)$ and beaded streams $(\mathrm{n}=13)$ account for the remaining thaw-affected area $(<1 \%$; Fig. 5).

363 Site L is the only study area where retrogressive thaw slump activity occurs. This study area 364 exhibits high spatial complexity, with 22 landforms per thermokarst-affected kilometer squared 365 (Fig. 7). Because no currently thermokarst affected lake margins were found, we suspect that 366 either the ice bodies bordering lakes in this study area have already melted-out, or that ice-bodies 367 are now protected by a layer of thawed material. Two stabilized retrogressive thaw slumps 368 belong to the category of previously thermokarst affected landforms. 
371 Based on 1,528 digitized individual landforms within 12 study areas covering a total of $300-\mathrm{km}^{2}$,

$37263 \%$ of the study landscape is currently or has been previously affected by thermokarst processes

373 (Figs. 3 and 4, Table 3). This leaves 37\% of the study area as non-thermokarst-affected terrain,

374 much of which is underlain by ice-rich permafrost (Kanevskiy et al., 2013), which implies it is

375 vulnerable to future thaw.

376 Thermokarst-lakes and drained thermokarst-lake basins are the most numerous and

377 spatially extensive thermokarst landforms across all geological substrates. Drained thermokarst-

378 lake basins cover $33 \%$ of the study area, and extant thermokarst-lakes $16 \%$. The third most

379 abundant type of landform are thermokarst troughs and pits, which cover $7 \%$ of the total study

380 area. Rarer landforms include alas and thaw valleys (6\% cover, mainly observed in regions

381 underlain by aeolian silt/ yedoma), drained thaw-ponds ( $<1 \%$ cover $)$, beaded streams $(<0.1 \%$

382 cover), retrogressive thaw slumps $(<0.1 \%$ cover, only observed in areas underlain by glacial

383 drift), and flooded ice-wedge polygons (<1\% cover, only observed in areas underlain by deltaic

384 sand and gravel).

385 In addition to being most numerous, drained thermokarst-lake basins are the thermokarst

386 landforms occupying the greatest mean surface area per individual feature, $62 \mathrm{ha}(\mathrm{n}=168)$.

387 Thermokarst-lakes have the second greatest mean surface area per individual feature, 24 ha $(\mathrm{n}=$

388 212). The smaller mean size of thermokarst-lakes compared to drained thermokarst-lake basins

389 results from the basins being formed by multiple generations of coalescent, drained lakes. Alas

390 and thaw valleys are the third largest landform with a mean area of $12 \mathrm{ha}(\mathrm{n}=88)$. The

391 landforms with the smallest mean size are drained thaw-ponds (area =1 ha; $\mathrm{n}=110$ ),

392 retrogressive thaw slumps $(3 \mathrm{ha} ; \mathrm{n}=2)$, zones of thermokarst troughs and pits $(3 \mathrm{ha} ; \mathrm{n}=887)$,

393 and beaded streams (4.8 ha; $\mathrm{n}=37)$. Mean elevation range of these landforms varies from $10.7 \mathrm{~m}$

394 (beaded streams) to $2.6 \mathrm{~m}$ (drained thaw-ponds). Overall, beaded streams and alas and thaw

395 valleys exhibit the highest mean elevation ranges, 10.7 and $9.0 \mathrm{~m}$, respectively (Table 4).

396

397 5. Discussion

398 5.1. Comparison with previous studies

399 Overall, our findings are similar to previous mapping efforts of permafrost-affected arctic

400 lowlands. Our cover estimates for thermokarst-lakes and drained thermokarst-lake basins in areas 401 of marine silt and sand align closely with previous results from the Arctic Coastal Plain of 
402 Alaska (Frohn et al., 2005; Hinkel et al., 2005; Wang et al., 2012; Jones and Arp, 2015; Table 2).

403 Mapped areas of yedoma areas in the lowlands of northern Siberia exhibit similar coverage by 404 thermokarst-lakes and drained thermokarst-lake basins as our study (Grosse et al., 2006, 2008;

405 Morgenstern et al., 2011; Tables 2 and 3). Although our estimates of percent cover by drained

406 thermokarst-lake basin at aeolian silt sites in the Arctic Foothills (34\%) agree with previous 407 studies in this region (Wang et al. 2012), they differ from observations in similar substrates on 408 the northern Seward Peninsula and in the Kolyma lowlands, where the distribution of drained 409 thermokarst-lake basins is much greater, around 75 (Jones et al., 2012) and 61\% (Veremeeva and 410 Gubin, 2009) respectively. This difference may be because most thermokarst-lakes on the 411 Seward Peninsula have developed on a flat plain rather than in the foothills. The mean slope for 412 the aeolian silt region of the Arctic Foothills is $0.30^{\circ}$ whereas the mean slope on the Seward 413 Peninsula lowlands is only $0.15^{\circ}$, which is similar to areas of marine sand in our study area. Finally, our results regarding beaded stream distribution generally agree with previous

415 416 417 418 419 420

\subsection{Distribution of landforms}

We found that regardless of underlying surficial geology, thermokarst-lake development is the dominant, thermokarst geomorphic process in lowland areas of Arctic Alaska, as mapped at this point in time. Thermokarst-lake development (thermokarst-lakes and drained thermokarst-lake basins combined) has affected $49 \%$ of the combined study areas and has been most intense in areas of marine silt and sand (Figs. 4 and 5). These areas typically are underlain by ice-rich permafrost and are relatively flat. In combination, both of these factors are conducive to repeated cycles of thermokarst pit, thermokarst pond and eventual thermokarst-lake, development. In contrast, thermokarst-lakes and drained thermokarst-lake basins are much less abundant in areas underlain by aeolian sand, aeolian silt, glacial drift, or deltaic deposits (Figs. 4 and 5).

Though less widespread, landforms like alas and thaw valleys and thermokarst troughs and pits are important components of Arctic Alaska's landscape. Alas and thaw valleys are 
432 largely restricted to areas underlain by aeolian silt, where they cover around $14 \%$ of the

433 landscape. In contrast, zones of thermokarst troughs and pits occur in all surficial geological 434 types, albeit at low densities. Altogether, zones of thermokarst troughs and pits cover $\sim 7 \%$ of 435 the combined study areas. The only surficial-geology type where they do not occur is in glacial 436 drift. This may result from the pronounced topographic relief there (mean slope there is $2^{\circ}$ ) that 437 creates good drainage conditions that inhibit extensive ice-wedge polygon pond development. 438 Thermokarst troughs and pits are most extensive in areas underlain by deltaic sands and gravels 439 and marine sands where they cover 18 and 12\%, respectively. Though not observed during this 440 study, it is important to note that thermokarst troughs and pits can also form within ancient 441 drained thermokarst-lake basins. Over hundreds to thousands of years, epigenetic ice-wedges $\mathbf{4 4 2}$ form within lacustrine sediments and terrestrial peat, and any disturbance to the ground thermal 443 regime can result in ice-wedge degradation.

444 Beaded stream channels cover only a small percentage of the landscape regardless of 445 surficial geology $(0.6 \%)$. Despite their restricted occurrence, beaded streams play an important 446 role in sediment and nutrient transport through tundra watersheds (Arp et al., 2015). Among the factors controlling the distribution of thermokarst landforms in Arctic Alaska, 448 the two most important are probably the volume of ground ice and the regional drainage 449 gradient. Cryolithology — the amount, structure, and spatial distribution of ice in the ground 450 strongly influences thermokarst processes (Jorgenson et al., 2008a; French and Shur, 2010). The 451 more ice there is underground, the greater effect its melting has on surface topography.

452 Topography also exerts a very basic control over the development of thermokarst landforms 453 through its effects on surface drainage. For instance, the greater topographic relief of the 454 northern Seward Peninsula compared to the Arctic Coastal Plain probably contributes to 455 differences in the abundances of alas valleys compared to thermokarst-lakes in areas of aeolian 456 silt in the two areas. One possible explanation for the low abundance of thermokarst-lakes in the 457 Arctic Foothills is that in aeolian silt areas the average terrain slope is steep enough to facilitate 458 the runoff of meltwater from degrading ice-wedge polygons. Meltwater then becomes 459 channelized instead of ponding and tends to form alas valleys rather than thermokarst-lakes. 460 Differences in environmental history may also explain some of the variability in 461 thermokarst landforms on different geological substrates in Arctic Alaska. The initiation and 462 expansion of peat occurred across Arctic Alaska and northern Siberia during postglacial times in 
463 a time-transgressive fashion (Mann et al., 2002; Macdonald et al., 2006). Earlier peat

464 accumulation in some areas may have formed an insulating layer (Baughman et al., 2015) that

465 shielded the underlying permafrost from later climatic perturbations and subsequent thaw

466 (Gagliotti et al., 2014).

467

The age of the landscape also influences the distribution of thermokarst landforms. On older surfaces, thermokarst processes have had more time to rework the landscape and, for instance, to cycle through multiple generations of thermokarst-lakes and drained-lake basins (Billings and Peterson, 1980; Jorgenson and Shur, 2007; Fig. 8). Results of this study show that older land surfaces (see section 2), including areas underlain by marine silt and marine sand,

472 contain the largest landforms: namely, drained thermokarst-lake basins and thermokarst-lakes. In

473 contrast, younger land surfaces like the Ikpikpuk Delta, support less thermokarst activity and 474 possess more abundant, smaller-scale landforms, mainly zones of thermokarst troughs and pits.

$475 \quad$ Older land surfaces may provide indications about the future, developmental trajectories

476 of younger landscapes. For instance, the relative abundance of thermokarst troughs and pits on 477 young surfaces may represent the initial stage of formation for other thaw-related landforms 478 including thermokarst-lakes (Czudek and Demek, 1970; Farquharson et al., 2016), beaded 479 streams (Arp et al., 2015), and in some cases, thaw-slumps (Burn and Lewkowicz, 1990).

\subsection{Landscape vulnerability to future thaw}

482

The vulnerability of permafrost terrain to thaw is mediated by the climate at the ground

483 surface, and the climate of Arctic Alaska is currently changing rapidly. In response, permafrost 484 temperatures are rising in all the surficial geology types we studied (Fig. 2). The fastest rates of 485 warming are in the glacial drift (up to $1.5^{\circ} \mathrm{C}$ increase between 2000 and 2011) and in aeolian silt 486 areas $\left(1.1^{\circ} \mathrm{C}\right.$ increase between 1999 and 2010). Interestingly, sites with the coldest $\left(-7.4^{\circ} \mathrm{C}\right)$ 487 permafrost are also the most thaw-affected, probably because they are more ice-rich than the 488 warmer $\left(-3.3^{\circ} \mathrm{C}\right)$ permafrost sites. Mean annual air temperature (MAATs) is projected to increase 489 in the Arctic by up to $8.3^{\circ} \mathrm{C}$ over the coming century (see IPCC, 2013, Table 22.2), and this will 490 undoubtedly cause further ground temperature warming in Arctic Alaska.

Changing climate is causing an increased frequency of wildland fires in Arctic Alaska 492 (Hu et al., 2015). Fire is a major threat to landscape stability there because it destroys the peat 493 layers that insulate the ground and buffer the underlying permafrost from changes in air 
494 temperature (Mack et al., 2011). Removal of these insulating peat layers from terrain underlain

495 by ice-rich permafrost can trigger drastic and widespread thermokarst (Jones et al., 2015). Our

496 finding that areas underlain by aeolian silt contain large areas (43\%) not yet affected by

497 thermokarst suggests this surficial geology type possesses a relatively high degree of resistance

498 to thaw. One possible explanation for this resistance is that the higher slope angle of this surficial

499 geology type compared to most others (Table 3) improves drainage conditions and inhibits

500 thermokarst. Alternatively, the presence of extensive areas of non-thaw-affected terrain in

501 yedoma areas may result from an earlier spread of insulating organic soils in post-glacial times,

502 which so far has buffered the underlying permafrost from periods of warm temperature (Mann et

503 al., 2010). If true, this implies that peat-supporting yedoma areas may now be highly vulnerable

504 to extensive thermokarst triggered by more frequent wildland fires.

505 Two surficial geology types in Arctic Alaska - marine silt, and aeolian silt — have high

506 potentials for severe thermokarst development based on their excess ice contents, and in the case

507 of aeolian silt, the amount of land area not previously affected by thermokarst. What these two

508 surficial geology types have in common is the presence of abundant silt. Silt is well-known for

509 its capacity for holding large amounts of excess ice (Yershov, 1998; French, 2007).

510 Of the two surficial geology types where future thermokarst can be expected to be most

511 severe, areas underlain by aeolian silt probably have the highest potential because they contain

512 deeply distributed excess ice (Jorgenson et al., 2008b; Kanevskiy et al., 2011; 2013; Fig. 4), and

513 a large proportion (43\%) of this surficial geology type has not been previously thermokarst

514 affected. Although areas underlain by marine silt also contain high amounts of excess ice, it is

515 mainly in the form of epigenetic ice-wedges restricted to the upper several meters of the ground.

516 Most of the terrain underlain by marine silt in our study region has already been reworked by

517 thermokarst processes during post-glacial times, and future thermokarst landform development

518 will be constrained to reworking these previously thermokarst-affected areas. These varying

519 magnitudes of potential thermokarst responses are reflected in the depth of thermokarst-related

520 surface settling revealed by bluff heights. The bluffs bordering drained thermokarst-lake basins

521 in areas underlain by marine silt average only $5.3 \mathrm{~m}$ in height, whereas bluffs in areas of aeolian

522 silt where excess ice contents are greater, average $19.3 \mathrm{~m}$ high (Table 4).

523 Predicting the future responses of permafrost landscapes to warming is particularly

524 challenging in areas already possessing complex thermokarst geomorphology. Different 
525 thermokarst landforms have varying mechanisms of thaw; hence different processes and rates 526 can drive future topographic changes. Using diversity and density of landforms as indicators of

527 landscape complexity reveals that areas underlain by aeolian silt are the most complex in terms

528 of thermokarst geomorphology (Fig. 7). These areas exhibit a high density of landforms (21.8

529 per $\mathrm{km}^{2}$ ) and a high diversity, with five different types of thermokarst landforms present. Areas 530 underlain by marine silt are the least complex, with low landform density (0.8 landforms per

$531 \mathrm{~km}^{2}$; Fig. 7), mainly because of the predominance of large drained-lake basins (Fig. 4, Table 4).

532 Areas with higher landform diversity will probably experience a more diverse array of

533 geomorphological responses to disturbances related to warming climate. Assessing the

534 vulnerability to future thaw in areas underlain by glacial drift and deltaic sands is particularly

535 challenging. Areas of glacial drift possess heterogeneous cryolithology and excess-ice content

536 because of the presence of buried glacial ice. The distribution of excess ice within areas of

537 deltaic sands is similarly unpredictable.

538

539 6. Conclusions

540 Results of this study improve understanding of future geomorphological responses to climate 541 change in permafrost landscapes underlain by different surficial geologies in Arctic Alaska.

542 Some of these results are also relevant to the ice-rich, coastal lowlands of northeast Siberia.

543 Thermokarst landforms are widespread in Arctic Alaska and cover $60 \%$ of the $300-\mathrm{km}^{2}$ area we

544 mapped. Some of these landforms are actively forming today, while others are relict features.

545 Thermokarst-lakes and drained thermokarst-lake basins comprise the majority of thermokarst-

546 affected terrain. Alas and thaw valleys and thermokarst troughs and pits are also widespread but

547 occur at low densities. Permafrost temperatures are currently rising throughout Arctic Alaska,

548 and widespread geomorphic changes related to permafrost thaw seem inevitable. Areas of marine

549 silt are highly vulnerable to future thaw because they tend to be ice rich in their near surface

550 sediments. However, because extensive thermokarst has already occurred in this surficial

551 geology type over the course of the Holocene, these areas contain only limited amounts of excess

552 ice in their upper few meters of sediment. The most severe thermokarst will probably occur in

553 areas of aeolian silt (yedoma) because large expanses of these surficial geology types have not

554 been previously disturbed by thaw (42\% of total), and they contain large amounts of ice in deep,

555 syngenetic ice-wedges formed during the coldest parts of the ice age. 
557 Acknowledgements

558 LMF thanks the Arctic Landscape Conservation Cooperative and USGS Alaska Climate Science 559 Center-funded Alaska Integrated Ecosystem Model Project for support. GG was supported by 560 ERC \#338335. DHM was partially supported by NSF grants ARC-0902169 and PLR-1417611.

561 Support for BMJ was provided by the USGS Land Change Science Program and Land Remote 562 Sensing Program. The Teshekpuk Lake Observatory was critical for field support. We thank

563 Reginald Muskett for assistance with permafrost temperature data, and Helene Genet for helpful 564 conversations that improved the paper. We would like to thank the editor Richard Marston, 565 Mikhail Kanevskiy, and three anonymous reviewers whose comments and suggestions greatly 566 improved the manuscript. Any use of trade, product, or firm names is for descriptive purposes 567 only and does not imply endorsement by the U.S. Government. Field logistics were provided in 568 part by grants from the Bureau of Land Management and the National Science Foundation (NSF569 PLR 1417611).

570

\section{$571 \quad$ References}

572

573

Are, F.E., 1978. The reworking of shorelines in the permafrost zone, In: Proceedings of the Second International Conference on Permafrost, USSR Contribution. US National Academy of Sciences, Washington, DC, pp. 59-62.

576 Arp, C.D., Jones, B.M., 2009. Geography of Alaska lake districts: identification, description, and 577 analysis of lake-rich regions of a diverse and dynamic state. U.S. Geol. Surv. Sci. Investig. 578 Rep. 2008-5215, 40.

579 Arp, C.D., Whitman, M.S., Jones, B.M., Grosse, G., Gaglioti, B. V., Heim, K.C., 2015.

580 Distribution and biophysical processes of beaded streams in Arctic permafrost landscapes. $581 \quad$ Biogeosciences 12, 29-47.

582 Balser, A.W., Jones, J.B., Gens, R., 2014. Timing of retrogressive thaw slump initiation in the 583 Noatak Basin, northwest Alaska, USA. J. Geophys. Res. Earth Surf. 119, 1106-1120.

584 Baughman, C.A., Mann, D.H., Verbyla, D.L., Kunz, M.L., 2015. Soil-surface organic layers in 585 Arctic Alaska: Spatial distribution, rates of formation, microclimatic effects. J. Geophys. 586 Res. Biogeosciences. 120, 1150-1164. 
587 Billings, W.D., Peterson, K.M., 1980. Vegetational change and ice-wedge polygons through the thermokarst-lake cycle in Arctic Alaska. Arct. Alp. Res. 413-432.

589 Burn, C.R., 1992. Thermokarst-lakes. Can. Geogr. 36, 81-85.

590 Burn, C.R., Lewkowicz, A.G., 1990. Retrogressive thaw slumps. Can. Geogr. 34, 273-276.

591 Carter, L.D., 1981. A Pleistocene sand sea on the Alaskan arctic coastal Plain. Science 211, 381592383.

593 Cohen, J., Screen, J.A., Furtado, J.C., Barlow, M., Whittleston, D., Coumou, D., Francis, J., 594 Dethloff, K., Entekhabi, D., Overland, J., Jones, J., 2014. Recent Arctic amplification and 595 extreme mid-latitude weather. Nat. Geosci. 7, 627-637.

596 Côté, M.M., Burn, C.R., 2002. The oriented lakes of Tuktoyaktuk Peninsula, western arctic

597

598

599

600

601

602

603

604

605

606

607

608

609

610

611

612

613

614 coast, Canada: a GIS-based analysis. Permafr. Periglac. Process. 13, 61-70.

Czudek, T., Demek, J., 1970. Thermokarst in Siberia and its influence on the development of lowland relief. Quat. Res. 1, 103-120

Dinter, D.A., Carter, L.D., Brigham-Grette, J., 1990. Late Cenozoic geologic evolution of the Alaskan North Slope and adjacent continental shelves, In: The Arctic Ocean Region, The Geology of North America 50: 459-489.

Farquharson, L.M., Anthony, K.W., Bigelow, N., Edwards, M., Grosse, G., 2016. Facies analysis of yedoma thermokarst-lakes on the northern Seward Peninsula, Alaska. Sediment. Geol. $340,25-37$

French, H. M., 2007. The periglacial environment. John Wiley and Sons. 370 pp.

French, H.M., Shur, Y., 2010. The principles of cryostratigraphy. Earth-Science Reviews 101, 190-206.

Frohn, R.C., Hinkel, K.M., Eisner, W.R., 2005. Satellite remote sensing classification of thaw lakes and drained thaw lake basins on the North Slope of Alaska. Remote Sens. Environ. 97, 116-126.

1 Gaglioti, B.V, Mann, D.H., Jones, B.M., Pohlman, J.W., Kunz, M.L., Wooller, M.J., 2014 3 Radiocarbon age-offsets in an arctic lake reveal the long-term response of permafrost 4 carbon to climate change. J. Geophys. Res. Biogeosciences 119, 557-566. 
615 Galloway, J.P., Carter, D. L., 1993. Late Holocene longitudinal and parabolic dunes in arctic

616

617

618

619

620

621

622

623

624

625

626

627

628

629

630

631

632

633

634

635

636

637

638

639

640

641

642

643

644

645

Alaska: Preliminary interpretations of age and paleoclimatic significance. United States Geological Survey Bulletin 2068: 3-11.

Goudie, A., 2004. Encyclopedia of geomorphology. Vol. 2. Psychology Press, 1200 pp.

Grosse, G., Schirrmeister, L., Malthus, T.J., 2006. Application of Landsat-7 satellite data and a DEM for the quantification of thermokarst-affected terrain types in the periglacial LenaAnabar coastal lowland. Polar Res. 25, 51-67.

Grosse, G., Romanovsky, V.E., Walter, K., Morgenstern, A., Lantuit, H., Zimov, S.A., 2008. Distribution of Thermokarst Lakes and Ponds at Three Yedoma Sites in Siberia, In: Ninth International Conferencnce on Permafrost. Institute of Northern Engineering, University of Alaska Fairbanks, Fairbanks, USA, pp. 551-556.

Grosse, G., Harden, J., Turetsky, M., McGuire, A.D., Camill, P., Tarnocai, C., Frolking, S., Schuur, E.A.G., Jorgenson, T., Marchenko, S., 2011. Vulnerability of high-latitude soil organic carbon in North America to disturbance. J. Geophys. Res. 116, G00K06.

Grosse, G., Jones, B., Arp, C., 2013. Thermokarst-lakes, drainage, and drained basins, In: Shroner Giardino, R., Harbor, J. (Eds.), Treatise on Geomorphology. Academic Press, San Diego, CA, pp. 325-353.

Hamilton, T.D., 2003. Glacial geology of the Toolik Lake and upper Kuparuk River regions, In: Walker, D.A. (Ed.), Biological Papers of the University of Alaska. p. 24.

Hinkel, K.M., Frohn, R.C., Nelson, F.E., Eisner, W.R., Beck, R.A., 2005. Morphometric and spatial analysis of thaw lakes and drained thaw lake basins in the westernArctic Coastal Plain, Alaska. Permafr. Periglac. Process. 16, 327-341.

Homer, C.G., Dewitz, J.A., Yang, L., Jin, S., Danielson, P., Xian, G., Coulston, J., Herold, N.D., Wickham, J.D., Megown, K., 2015. Completion of the 2011 National Land Cover Database for the conterminous United States-Representing a decade of land cover change information. Photogramm. Eng. Remote Sensing 81, 345-354.

Hu, F.S., Higuera, P.E., Duffy, P., Chipman, M.L., Rocha, A. V, Young, A.M., Kelly, R., Dietze, M.C., 2015. Arctic tundra fires: natural variability and responses to climate change. Front. Ecol. Environ. 13, 369-377.

Intermap, 2010. Product Handbook and Quick Start Guide, Standard Edition. Intermap, p. v 4.4. IPCC, 2013. Climate change 2013: the physical science basis. Intergov. Panel Clim. Chang. 
646 Jones, B.M., Arp, C.D., 2015. Observing a Catastrophic Thermokarst Lake Drainage in Arctic 647 Alaska. Permafr. Periglac. Process. 26, 119-128

648 Jones, B.M., Grosse, G., Arp, C.D., Jones, M.C., Walter Anthony, K., Romanovsky, V.E., 2011.

649 Modern thermokarst-lake dynamics in the continuous permafrost zone, northern Seward 650 Peninsula, Alaska. J. Geophys. Res. 116, 2005-2012.

651 Jones, B.M., Grosse, G., Arp, C.D., Miller, E., Liu, L., Hayes, D.J., Larsen, C.F., 2015. Recent

652 Arctic tundra fire initiates widespread thermokarst development. Sci. Rep. 5, 15865

653 Jones, M.C., Grosse, G., Jones, B.M., Walter Anthony, K.M., 2012. Peat accumulation in a

654 thermokarst-affected landscape in continuous ice-rich permafrost, Seward Peninsula,

655 Alaska. J. Geophys. Res. - Biogeosciences. 117(G2).

656 Jorgenson, M. T., 2013. Thermokarst terrains, In: Treatise on Geomorphology, Vol 8, Glacial

657 and Periglacial Geomorphology, edited by: Shroder, J.F. (Ed.), Giardino, R., Harbor, J.

658 (Vol. Eds.), Academic Press, San Diego, 313-324.

659 Jorgenson, M.T., Shur, Y., 2007. Evolution of lakes and basins in arctic Alaska and discussion of 660 the thaw lake cycle. J. Geophys. Res. Earth Surf. 112(F2).

661 Jorgenson, M. T., Shur, Y. L., Walker, H. J., 1998. Evolution of a permafrost-dominated 662 landscape on the Colville River Delta, northern Alaska. In: Lewkowicz, A.G., Allard, M., 663 (Eds.), Seventh International Conference on Permafrost. Collection Nordica, Yellowknife, 664 Canada pp. 523-529.

665 Jorgenson, M.T., Shur, Y.L., Pullman, E.R., 2006. Abrupt increase in permafrost degradation in 666 Arctic Alaska. Geophys. Res. Lett. 33.

667 Jorgenson, M.T., Shur, Y.L., Osterkamp, T.E., 2008a. Thermokarst in Alaska, In: Kane, D.L., 668 Hinkel (Eds.), Ninth International Conference on Permafrost. Institute of Northern 669 Engineering, University of Alaska Fairbanks, Fairbanks, Alaska, pp. 869-876.

670 Jorgenson, M.T., Yoshikawa, K., Kanevskiy, M., Shur, Y., Romanovsky, V.E., Marchenko, S., 671 Grosse, G., Brown, J., Jones, B., 2008b. Permafrost Characteristics of Alaska - A new 672 permafrost map of Alaska, In: Kane, D.L., Hinkel, K.M. (Eds.), Ninth International 673 Conference on Permafrost. Institute of Northern Engineering, University of Alaska $674 \quad$ Fairbanks, Fairbanks, Alaska, pp. 551-556. 
675 Jorgenson, T., Kanevskiy, M.Z., Shur, Y., Moskalenko, N.G., Brown, D.R.N., Wickland, K.,

676 Striegl, R., Koch, J., 2015. Ground ice dynamics and ecological feedbacks control ice-

677 wedge degradation and stabilization. JGR Earth Surface 120 (11): 2280-2297.

678 Kanevskiy, M., Shur, Y., Fortier, D., Jorgenson, M.T., Stephani, E., 2011. Cryostratigraphy of

679 late Pleistocene syngenetic permafrost (yedoma) in arctic Alaska, Itkillik River exposure.

680 Quat. Res. 75, 584-596.

681 Kanevskiy, M., Shur, Y., Jorgenson, M.T., Ping, C.L., Michaelson, G.J., Fortier, D., Stephani,

682 E., Dillon, M., Tumskoy, V., 2013. Ground ice in the upper permafrost of the Beaufort Sea

683 coast of Alaska. Cold Reg. Sci. Technol. 85, 56-70.

684 Kokelj, S.V, Jenkins, R.E., Milburn, D., Milburn, D., Burn, C.R., Snow, N.B., Burn, C.R., Snow,

685 N., 2005. The influence of thermokarst disturbance on the water quality of small upland

686 lakes, Mackenzie Delta region, Northwest Territories, Canada. Permafr. Periglac. Process.

$687 \quad 16,343-353$.

688 Kokelj, S.V., Lantz, T.C., Kanigan, J., Smith, S.L., Coutts, R., 2009. Origin and polycyclic

689 behaviour of tundra thaw slumps, Mackenzie Delta region, Northwest Territories, Canada.

690 Permafr. Periglac. Process. 20, 173-184.

691 Kokelj, S.V., Jorgenson, M.T., 2013. Advances in Thermokarst Research. Permafrost and

692 Periglacial Processes 24, 108-119.

693 Lamoureux, S.F., Lafreniére, M.J., 2009. Fluvial impact of extensive active layer detachments,

694 Cape Bounty, Melville Island, Canada. Arctic, Antarct. Alp. Res. 41, 59-68.

695 Lantuit, H., Pollard, W.H., 2008. Fifty years of coastal erosion and retrogressive thaw slump

696 activity on Herschel Island, southern Beaufort Sea, Yukon Territory, Canada.

697 Geomorphology 95, 84-102.

698 Lantz, T.C., Kokelj, S.V, 2008. Increasing rates of retrogressive thaw slump activity in the

699 Mackenzie Delta region, N.W.T., Canada. Geophys. Res. Lett. 35, 1-5.

700 Lewkowicz, A.G., Harris, C., 2005. Morphology and geotechnique of active-layer detachment

701 failures in discontinuous and continuous permafrost, northern Canada. Geomorphology 69, $702 \quad 275-297$.

703 Liljedahl, A.K., Boike, J., Daanen, R.P., Fedorov, A.N., Frost, G.V., Grosse, G., Hinzman, L.D., 704 Iijma, Y., Jorgenson, J.C., Matveyeva, N., Necsoiu, M., Raynolds, M.K., Romanovsky, V., 705 Schulla, J., Tape, K.D., Walker, D.A., Wilson, C., Yabuki, H., Zona, D., 2016. Pan-Arctic 
ice-wedge degradation in warming permafrost and influence on tundra hydrology. Nat. Geosci. 9, 312-318.

Macdonald, G.M., Beilman, D.W., Kremenetski, K. V, Sheng, Y., Smith, L.C., Velichko, A.A., 2006. Rapid early development of circumarctic peatlands and atmospheric $\mathrm{CH} 4$ and $\mathrm{CO} 2$ variations. Science 314, 285-288.

Mack, M.C., Bret-Harte, M.S., Hollingsworth, T.N., Jandt, R.R., Schuur, E.A., Shaver, G.R., Verbyla, D.L., 2011. Carbon loss from an unprecedented Arctic tundra wildfire. Nature, 475(7357), 489-492.

Mann, D.H., Peteet, D.M., Reanier, R.E., Kunz, M.L., 2002. Responses of an arctic landscape to lateglacial and early holocene climatic changes: The importance of moisture. Quat. Sci. Rev. 21, 997-1021.

Mann, D.H., Groves, P., Reanier, R.E., Kunz, M.L., 2010. Floodplains, permafrost, cottonwood trees, and peat: What happened the last time climate warmed suddenly in arctic Alaska? Quat. Sci. Rev. 29, 3812-3830.

Morgenstern, A., Grosse, G., Günther, F., Fedorova, I., Schirrmeister, L., 2011. Spatial analyses of thermokarst-lakes and basins in Yedoma landscapes of the Lena Delta. The Cryosphere $5,849-867$.

Myers-Smith, I.H., Harden, J.W., Wilmking, M., Fuller, C.C., McGuire, A.D., Chapin III, F.S., 2007. Wetland succession in a permafrost collapse: interactions between fire and thermokarst. Biogeosciences Discuss. 4(6), 4507-4538

Olthof, I., Fraser, R.H., Schmitt, C., 2015. Landsat-based mapping of thermokarst-lake dynamics on the Tuktoyaktuk Coastal Plain, Northwest Territories, Canada since 1985. Remote Sens. Environ. 168, 194-204.

Raynolds, M.K., Walker, D.A., Maier, H.A., 2006. Alaska Arctic Tundra Vegetation Map. Scale 1:4,000,000. Conservation of Arctic Flora and Fauna Map.

Raynolds, M.K., Walker, D.A., Ambrosius, K.J., Brown, J., Everett, K.R., Kanevskiy, M., Kofinas, G.P., Romanovsky, V.E., Shur, Y., Webber, P.J., 2014. Cumulative geoecological effects of 62 years of infrastructure and climate change in ice-rich permafrost landscapes, Prudhoe Bay Oilfield, Alaska. Glob. Chang. Biol. 20, 1211-1224.

Romanovsky, V.E., Smith, S.L., Christiansen, H.H., 2010. Permafrost thermal state in the polar northern hemisphere during the international polar year 2007-2009: A synthesis. Permafr. 
Periglac. Process. 21, 106-116.

Romanovsky, V. E., Smith, S.L., Christiansen, H.H., Shiklomanov, N.I., Streletskiy, D.A., Drozdov, D.S., Malkova, G.V., Oberman, N.G., Kholodov, A.L., Marchenko, S.S, 2015. Terrestrial Permafrost (in "State of the Climate in 2014”). Bull. Amer. Meteor. Soc., 96(7) S139-S141, 2015

Schirrmeister, L., Froese, D., Tumskoy, V., Grosse, G., Wetterich, S., 2013. Yedoma: Late Pleistocene ice-rich syngenetic permafrost of Beringia. Encyclopedia of Quaternary Science. 2nd edition, 542-552. In: S. Elias, S., Mock, C., Murton, J., (Eds.), Encyclopedia of Quaternary Science. 2nd edition, Amsterdam, Elsevier, 3888 p

Shur, Y.L., Jorgenson, M.T., 1998. Cryostructure development on the floodplain of the Colville River Delta, arctic Alaska, In: Lewkowicz, A.G., Allard, M. (Eds.), Seventh International Conference on Permafrost. Collection Nordica, Yellowknife, Canada.

Smith, S.L., Romanovsky, V.E., Lewkowicz, A.G., Burn, C.R., Allard, M., Clow, G.D., Yoshikawa, K., Throop, J., 2010. Thermal state of permafrost in North America: A contribution to the International Polar Year. Permafr. Periglac. Process. 21, 117-135.

Soloviev, P.A., 1973. Thermokarst phenomena and landforms due to frost heaving in central Yakutia, Builetyn perglacjalny 23, 135-155.

Steedman, A.E., Lantz, T.C., Kokelj, S.V., 2016. Spatio-Temporal Variation in High-Centre Polygons and Ice-Wedge Melt Ponds, Tuktoyaktuk Coastlands, Northwest Territories. Permafr. Periglac. Process.

van Everdingen, R., 2005. Multi-language glossary of permafrost and related ground-ice terms. Natl. Snow Ice Data Center/World Data Cent. Glaciol. Boulder.

Veremeeva, A., Gubin, S., 2009. Modern tundra landscapes of the Kolyma Lowland and their evolution in the Holocene. Permafrost and Periglacial Processes, 20(4), 399-406.

Wahrhaftig, C., 1965. Physiographic Divisions of Alaska, Geological Survey Professional Paper 482.

Wang, J., Sheng, Y., Hinkel, K.M., Lyons, E.A., 2012. Drained thaw lake basin recovery on the western Arctic Coastal Plain of Alaska using high-resolution digital elevation models and remote sensing imagery. Remote Sensing of Environment 119, 325-336.

Washburn, A.L., 1979. Geocryology: a survey of periglacial processes and environments. Edward Arnold, London, 416 pp. 
768

769

770

771

772

773

774

Wendler, G., Shulski, M., Moore, B. 2010. Changes in the climate of the Alaskan North Slope and the ice concentration of the adjacent Beaufort Sea. Theoretical and Applied Climatology 99, 67-74.

Yershov, E.D., 1998. General Geocryology. Cambridge University Press, Cambridge, 580 pp.

.

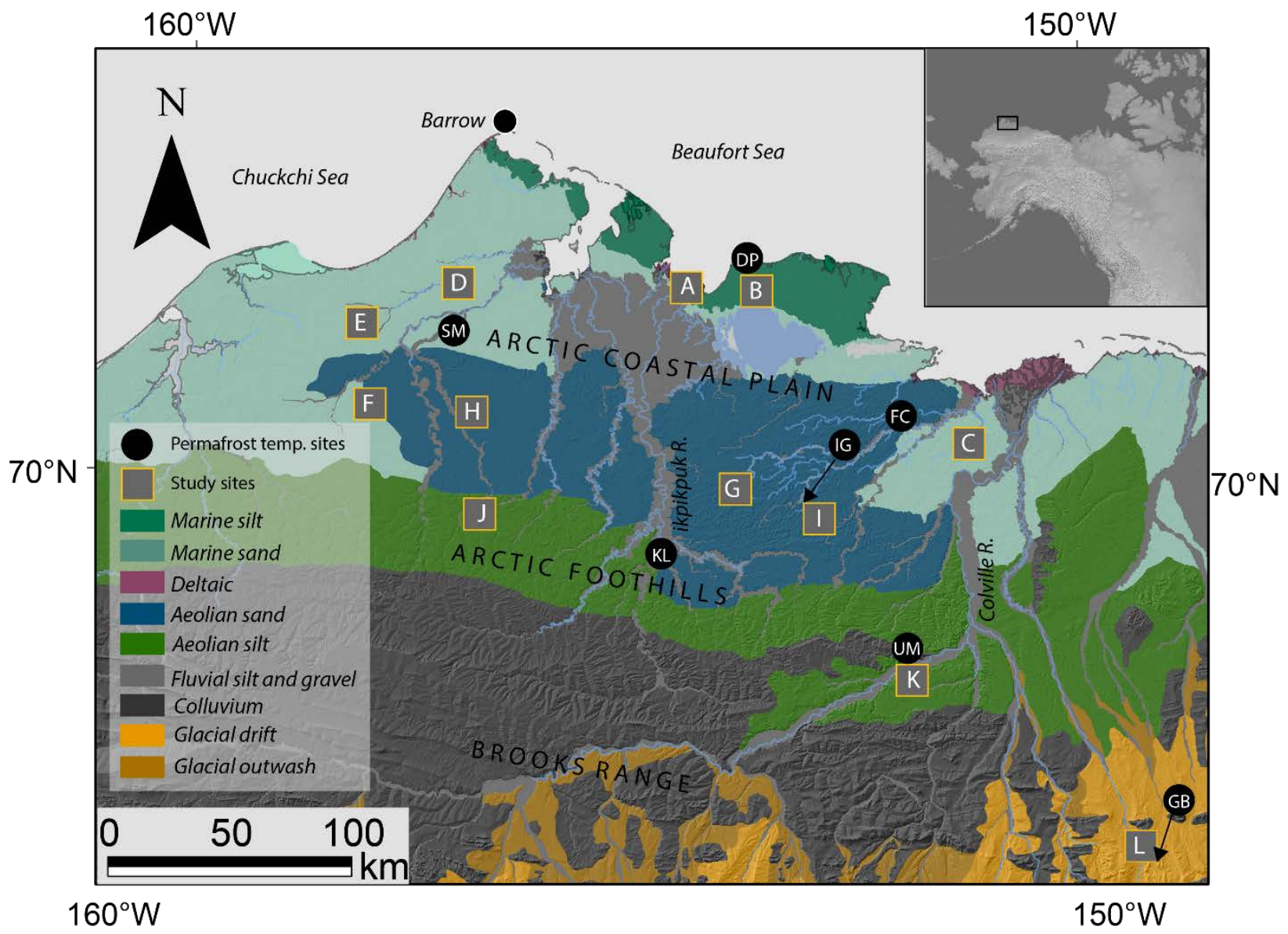

777 Fig. 1. The study area in northern Alaska. Squares indicate locations of 5 x $5 \mathrm{~km}$ areas where we 778 mapped thermokarst landforms. Surficial geology base map was modified from Jorgenson et al.

779 (2008). Permafrost borehole sites are marked as black circles: DP: Drew Point, SM: South 780 Meade, FC: Fish Creek, IG: Inigok, KL: Koluktak, UM: Umiat, GB: Galbraith. 
1999 - 2011 average soil temperature

$1.2 \mathrm{~m}$ depth

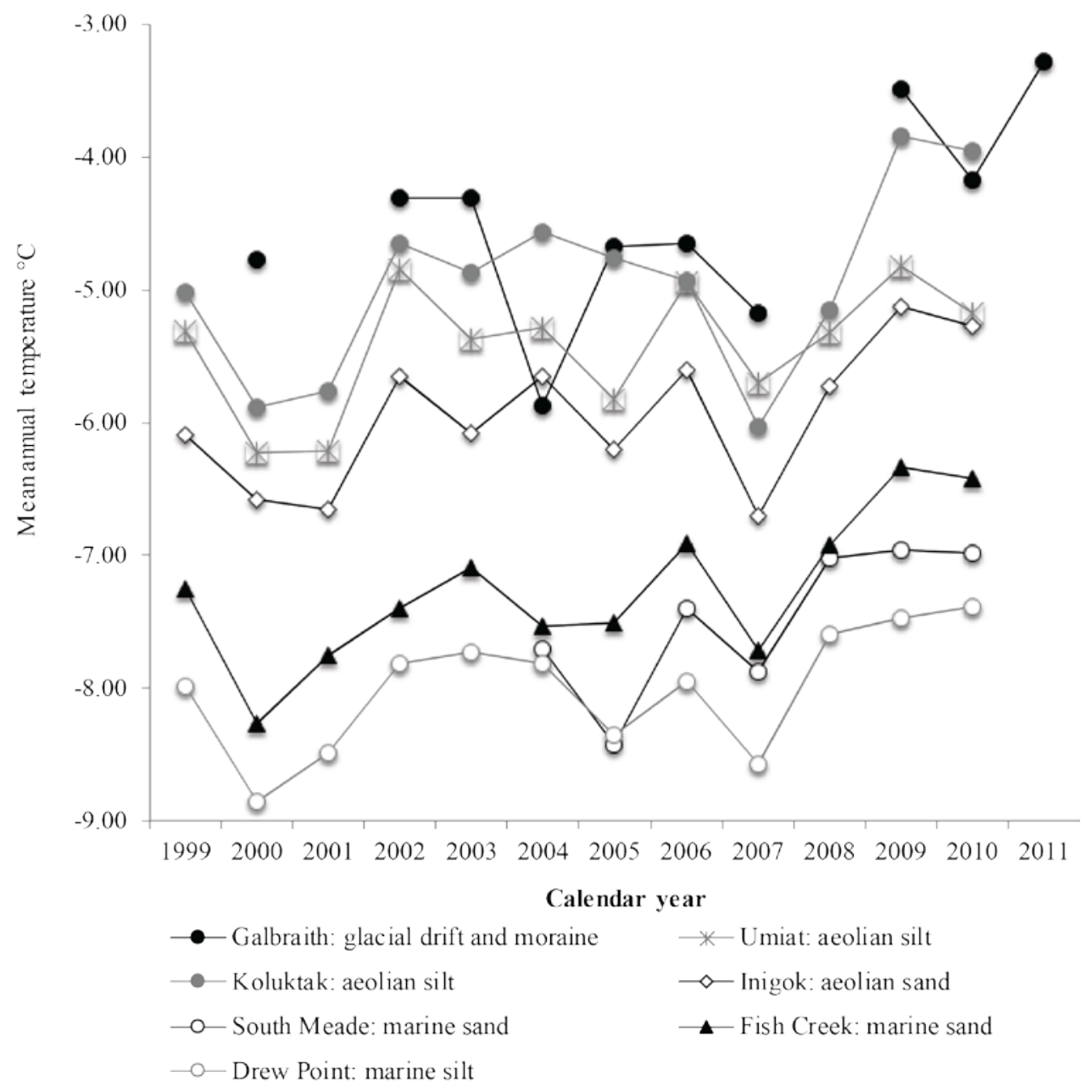

784

785

786 Fig. 2. Mean annual ground temperatures at $1.2 \mathrm{~m}$ depth (except for Galbraith, $1.0 \mathrm{~m}$ ) for

787 calendar years 1999-2011. All data sets acquired from USGS with the exception of Galbraith,

788 which was acquired from the Geophysical Institute Permafrost Laboratory, University of Alaska.

789

790

791 

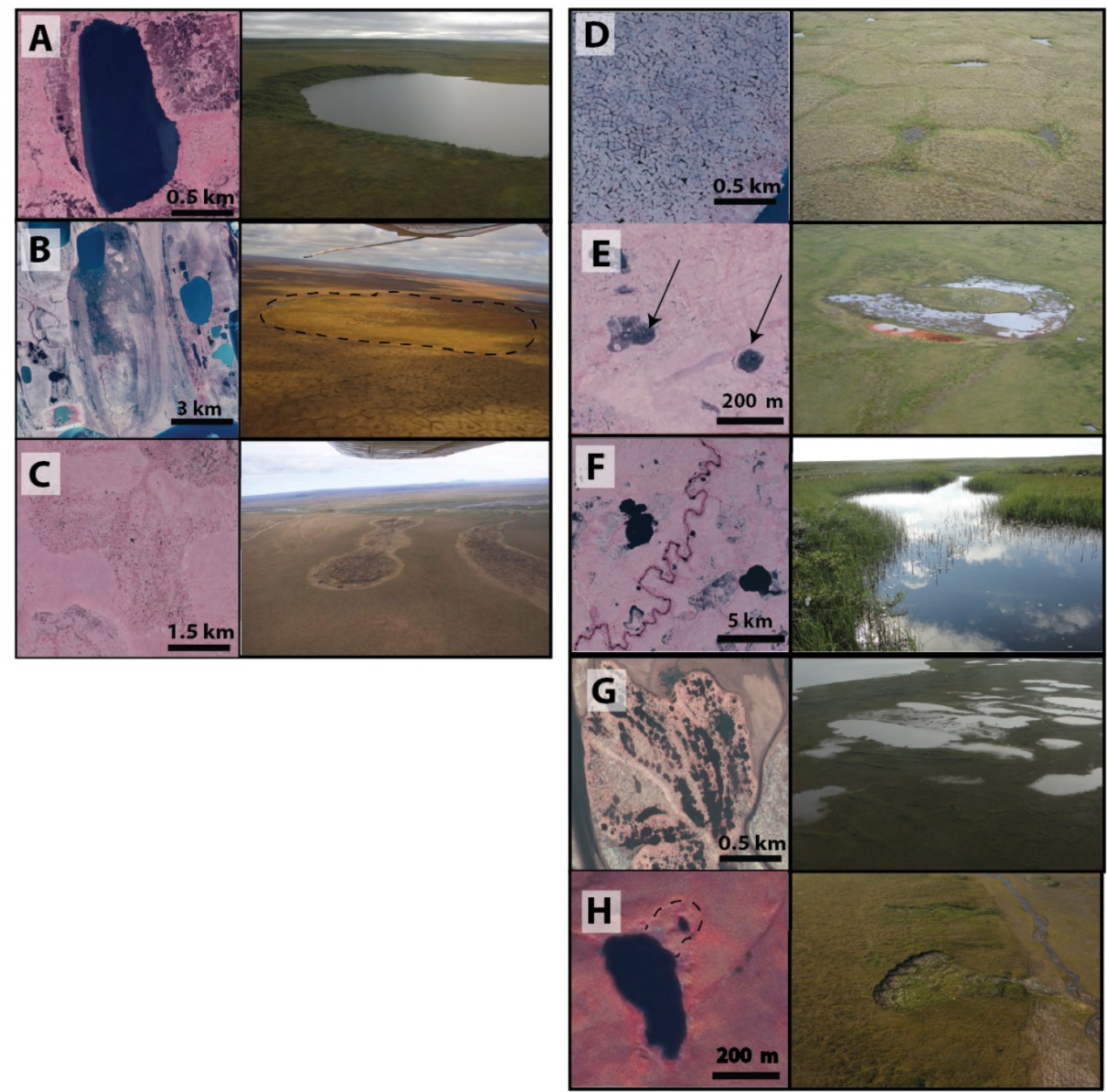

795 Fig. 3. Mapped landforms in planview (left) and oblique view (right). (A) thermokarst-lake, (B)

796 drained thermokarst-lake basin, (C) alas valley (morphology similar to thaw valley), (D)

797 thermokarst troughs and pits, (E) drained thaw-pond, (F) beaded stream, (G) flooded ice-wedge

798 polygons, $(\mathrm{H})$ retrogressive thaw-slump. Oblique photos are for descriptive purposes and not

799 necessarily from the locations shown in the aerial photos.

800

801 
Deltaic sands

and gravels

Marine silt

Marine sand
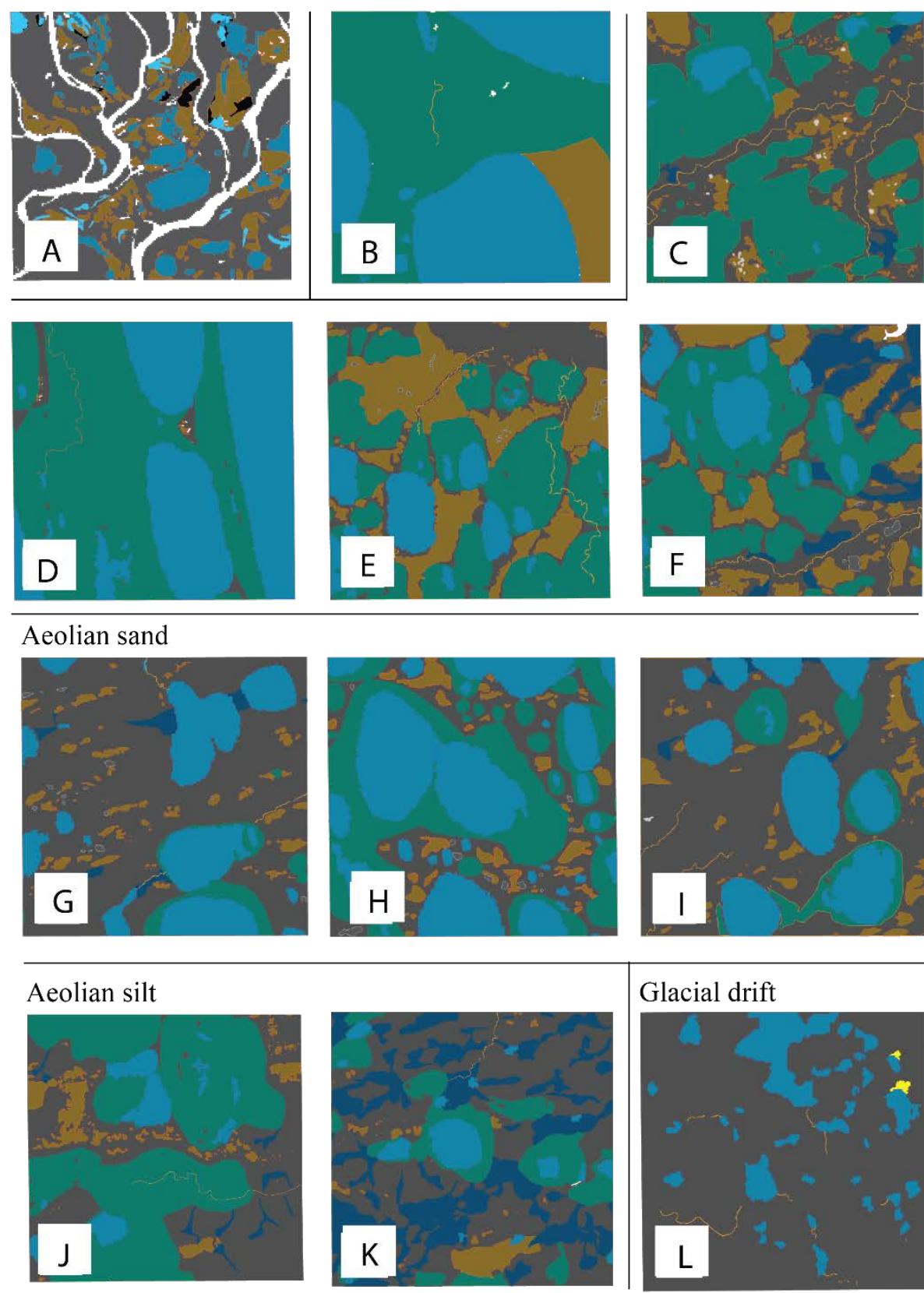

Glacial drift

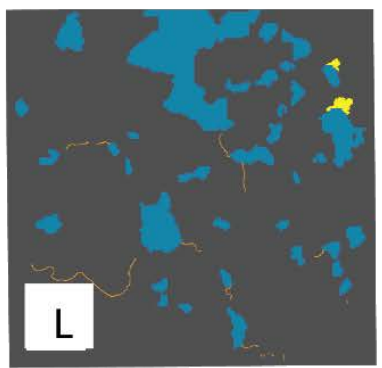

\section{$5 \mathrm{~km}$}

804 Fig. 4. Mapped areas grouped by surficial geology. Letters correspond to those in Fig. 1. 


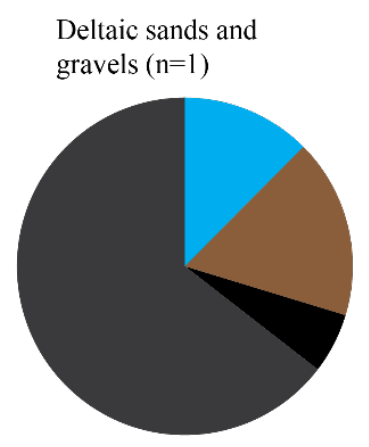

Aeolian sand $(\mathrm{n}=3)$

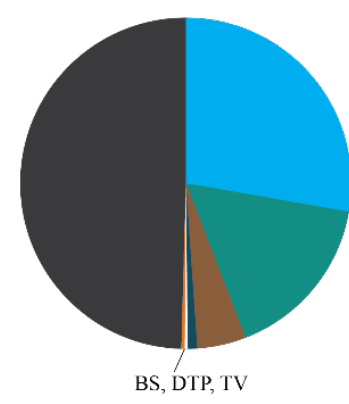

Marine silt ( $\mathrm{n}=1)$

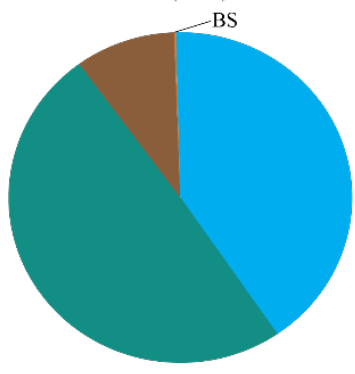

Aeolian silt ( $\mathrm{n}=2)$

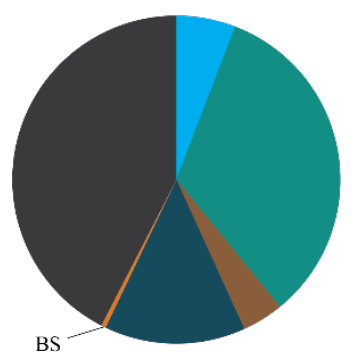

BS
Marine sand $(n=4)$

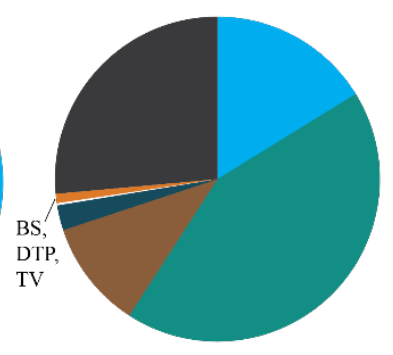

Glacial drift $(n=1)$

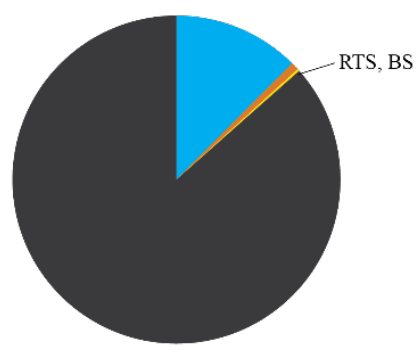

805

806

807 Fig. 5. Distribution of thermokarst landforms in relation to surficial geology. The $n$ values

808 indicate number of study areas underlain by each of the six surficial geology units. BS: beaded

809 stream, DTP: drained thaw pond, TV: thaw valley, RTS: retrogressive thaw slump.

810

811

812

813

814

815

816

817

818

819

820 


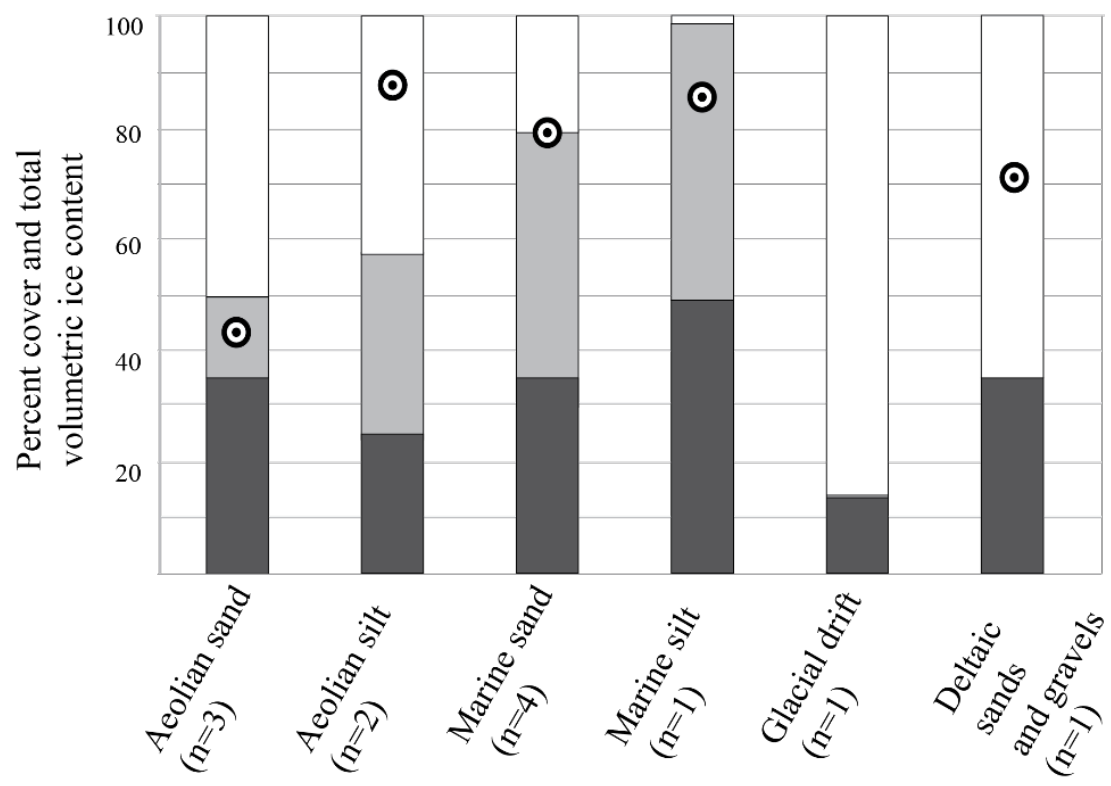

Currently active thermokarst $\quad \square$ Currently inactive thermokarst

No thermokarst activity observed $\mathbf{O}$ Total volumetric ground ice

821 (Kanevskiy et al. 2013)

822 Fig. 6. Relationships between thermokarst, surficial geology, and the amount of ground ice

823 present. No estimates of ground ice are available for the glacial drift area.

824

825

826

827

828

829

830

831

832

833

834

835

836

837

838 


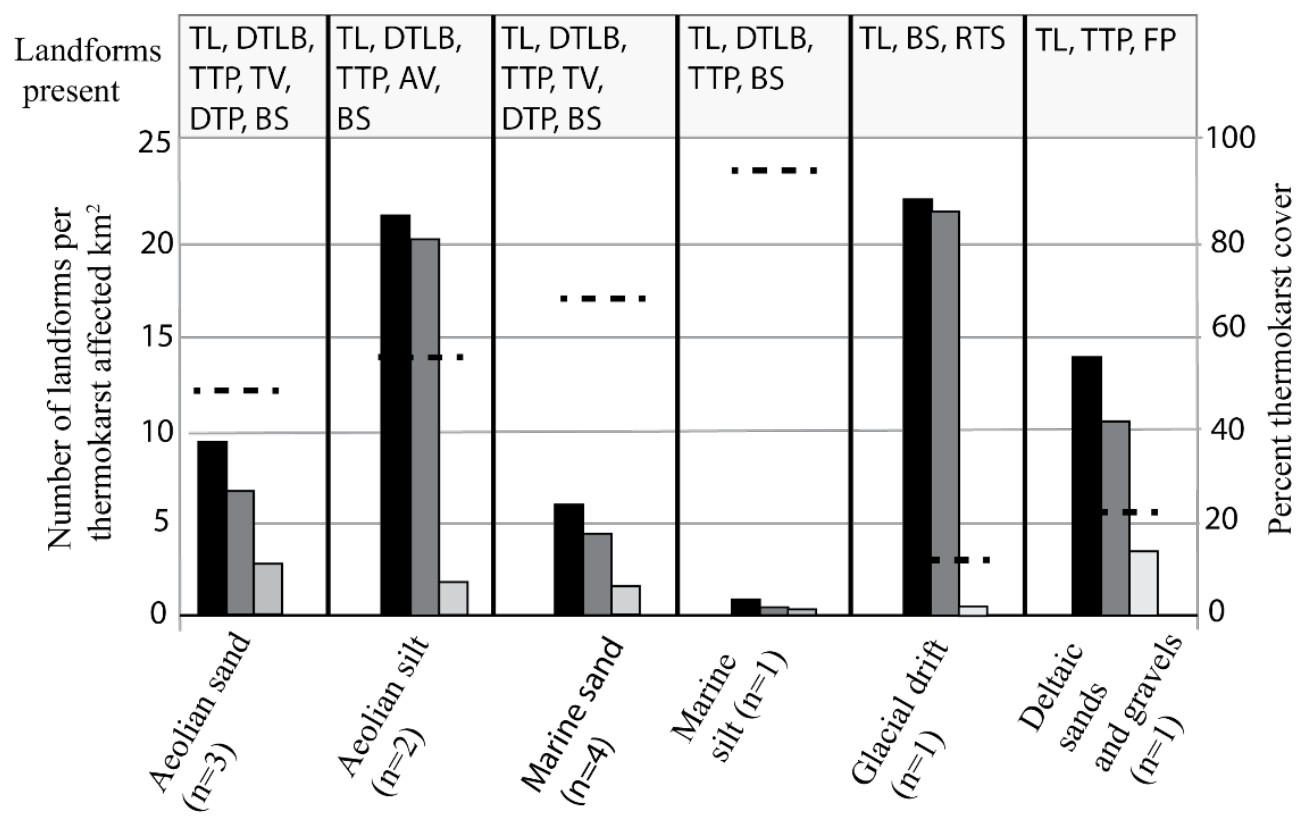

Currently active thermokarst

Currently inactive thermokarst

839

Both active and inactive combined

\section{0}

841 Fig. 7. Relationships between surficial geology, the amount of thermokarst that occurs, and what

842 form this thermokarst takes. Solid bars show the number of individual, thermokarst landforms

843 per $\mathrm{km}^{2}$ in areas of differing surficial geology. Dotted lines correspond to right-hand axis and

844 indicate what percentage of that type of lithology is or has been affected by thermokarst. TL:

845 thermokarst-lake, DTLB: drained thermokarst-lake basin, TTP: zones of thermokarst troughs and

846 pits, AV: alas valley, TV: thaw valley, DTP: drained thaw ponds, BS: beaded stream, RTS:

847 retrogressive thaw slump, FP: zones of flooded ice-wedge polygons.

848

849

850 

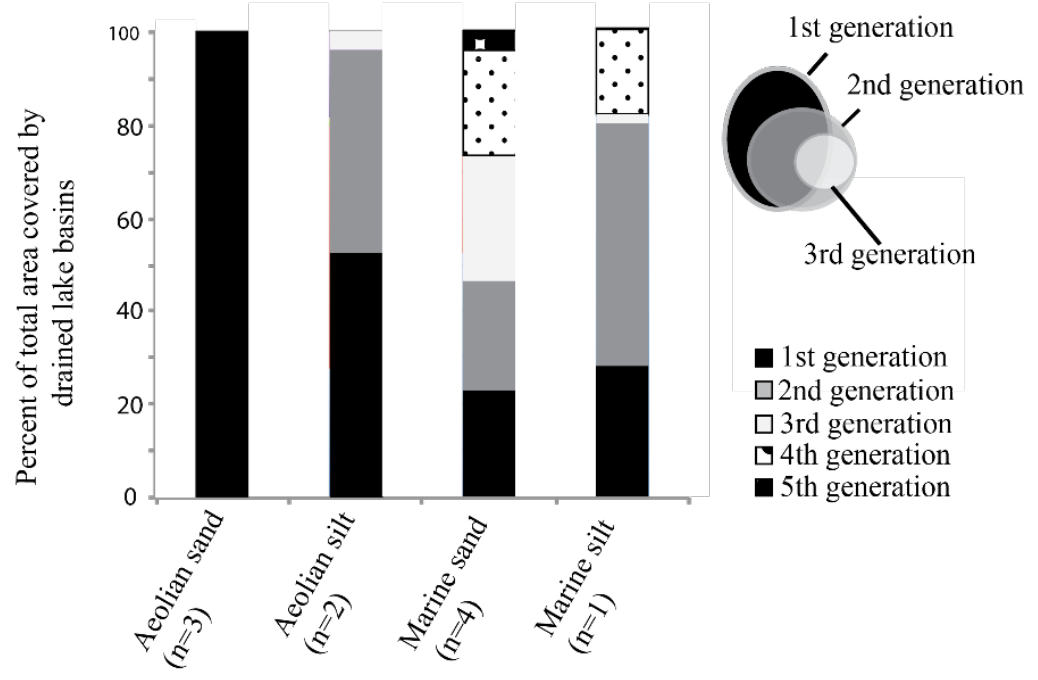

854

855

856 Fig. 8. Number of drained thermokarst-lake generations observed (see example, top right) in

857 areas of differing surficial geology. Study areas L (glacial drift) and A (deltaic sands and gravels)

858 are not shown because no drained thermokarst-lake basins were mapped there.

859

860 


\section{Table 1}

862 Percent cover of different types of surficial geology in the study region, the number of surveyed

863 areas mapped, mean slope of these survey areas, and estimated ice content.

\begin{tabular}{lllll} 
Surficial geology & $\begin{array}{l}\text { \% of study } \\
\text { area shown } \\
\text { in Figure 1 }\end{array}$ & $\begin{array}{l}\text { Polygons } \\
\text { mapped }\end{array}$ & $\begin{array}{l}\text { Mean } \\
\text { slope }\left({ }^{\circ}\right)\end{array}$ & $\begin{array}{l}\text { Mean } \\
\text { volumetric ice } \\
\text { content (\%) } \\
\text { (Kanevsky et } \\
\text { al. 2013) }\end{array}$ \\
\hline $\begin{array}{l}\text { Deltaic sands and } \\
\text { gravels }\end{array}$ & 2 & $\mathrm{~A}$ & 0.04 & 73 \\
Marine silt & 4 & $\mathrm{~B}$ & 0.03 & 86 \\
Marine sand & 33 & $\mathrm{C}, \mathrm{D}, \mathrm{E}, \mathrm{F}$ & 0.1 & 80 \\
Aeolian sand & 23 & $\mathrm{G}, \mathrm{H}, \mathrm{I}$ & 0.1 & 43 \\
Aeollian silt & 35 & $\mathrm{~J}, \mathrm{~K}$ & 0.32 & 89 \\
Glacial drift & 2 & $\mathrm{~L}$ & 2.04 & no data \\
\hline
\end{tabular}

864

865

866

867

868

869

870

871

872

873

874

875

876

877

878

879 
Table 2

881 Previous estimates of coverage by thaw lakes and drained thermokarst-lake basins in Alaska and

882 Siberia.

\begin{tabular}{|c|c|c|c|c|c|c|c|}
\hline Reference & Study area & Surficial Geology & $\begin{array}{l}\text { TK lake } \\
\% \text { cover }\end{array}$ & $\begin{array}{l}\text { Drained } \\
\text { TK lake } \\
\% \text { cover }\end{array}$ & $\begin{array}{l}\text { Alas valley } \\
\% \text { cover }\end{array}$ & $\begin{array}{l}\text { Zones of } \\
\text { thermokarst } \\
\text { troughs and } \\
\text { pits \% }\end{array}$ & $\begin{array}{l}\text { Beaded } \\
\text { streams } \\
\% \text { cover }\end{array}$ \\
\hline Hinkel et al. 2003 & Barrow Peninsula & Marine silt and marine sand & 22 & 50 & - & - & - \\
\hline Frohn et al. 2005 & Arctic Coastal Plain & Mixed & 20 & 26 & - & - & - \\
\hline Frohn et al. 2005 & Inner Coastal Plain & Aeolian sand & 14 & 22 & - & - & - \\
\hline Frohn et al. 2005 & Outer coastal Plain & Marine sand and silt & 22 & 45 & - & - & - \\
\hline Jones and Arp 2015 & Outer coastal Plain & Marine silt & 23 & 62 & - & - & - \\
\hline Arp and Jones 2009 & Northern Seward Peninsula & Aeolian silt & 7 & - & - & - & - \\
\hline Jones et al. 2012 & Northern Seward Peninsula & Aeolian silt & - & 76 & - & - & - \\
\hline Morgenstern et al. 2011 & Lena Delta & Yedoma (similar to Aeolian silt) & 5.2 & 20 & 42.5 & - & - \\
\hline Grosse et al. 2005 & Bykovsky Peninsula & Yedoma (similar to Aeolian silt) & 10.2 & 31.2 & - & - & - \\
\hline Grosse et al. 2008 & Bykovsky Peninsula & Yedoma (similar to Aeolian silt) & 15 & - & - & - & - \\
\hline Grosse et al. 2006 & Laptev Sea region & Yedoma (similar to Aeolian silt) & 7 & - & - & - & - \\
\hline Grosse et al. 2008 & Cherskii & Yedoma (similar to Aeolian silt) & $>1$ & - & - & - & - \\
\hline Grosse et al. 2008 & SW Lena Delta & Yedoma (similar to Aeolian silt) & 13 & - & - & - & - \\
\hline Jorgenson et al. 2008 & $\begin{array}{l}\text { Continuous permafrost zone, } \\
\text { Alaska }\end{array}$ & Mixed & 1.9 & 7.1 & - & 2.3 & 0.4 \\
\hline Veremeeva and Gubin 2009 & Kolyma Lowland & Yedoma (similar to Aeolian silt) & - & $53.5^{*}$ & - & 8 & - \\
\hline
\end{tabular}


$891 \quad$ Table 3

892 Percent cover of thermokarst landforms according to type of surficial geology; weighted percentages calculated using extent of

893 surficial geology area shown in Fig. 1 and described in section 2, (TL: thermokarst-lake, DTLB: drained thermokarst-lake basin, TTP:

894 zones of thermokarst troughs and pits, AV: alas valley, TV: thaw valley, DP: drained thaw ponds, BS: beaded stream, FP: zones of

895 flooded ice-wedge polygons, RTS: retrogressive thaw slump)

\begin{tabular}{|c|c|c|c|c|c|c|c|c|c|c|c|c|c|}
\hline & \multicolumn{2}{|c|}{$\begin{array}{l}\text { Deltaic sand and } \\
\text { gravel }\end{array}$} & \multicolumn{2}{|c|}{ Marine silt } & \multicolumn{2}{|c|}{ Marine sand } & \multicolumn{2}{|c|}{ Aeolian sand } & \multicolumn{2}{|c|}{ Aeolian silt } & \multicolumn{2}{|c|}{ Glacial drift } & \multirow{2}{*}{$\begin{array}{l}\text { Whole } \\
\text { study } \\
\text { region }\end{array}$} \\
\hline & $\begin{array}{l}\% \text { Cover } \\
\text { of study } \\
\text { area }\end{array}$ & $\begin{array}{l}\text { Wtd \% } \\
\text { Cover } \\
\text { region }\end{array}$ & $\begin{array}{l}\% \text { Cover } \\
\text { of study } \\
\text { area }\end{array}$ & $\begin{array}{l}\text { Wtd \% } \\
\text { Cover } \\
\text { region }\end{array}$ & $\begin{array}{l}\% \text { Cover } \\
\text { of study } \\
\text { area }\end{array}$ & $\begin{array}{l}\text { Wtd \% } \\
\text { Cover } \\
\text { region }\end{array}$ & $\begin{array}{l}\% \text { Cover } \\
\text { of study } \\
\text { area }\end{array}$ & $\begin{array}{l}\text { Wtd \% } \\
\text { Cover } \\
\text { region }\end{array}$ & $\begin{array}{l}\text { \% Cover } \\
\text { of study } \\
\text { area }\end{array}$ & $\begin{array}{l}\text { Wtd \% } \\
\text { Cover } \\
\text { region }\end{array}$ & $\begin{array}{l}\text { \% Cover } \\
\text { of study } \\
\text { area }\end{array}$ & $\begin{array}{l}\text { Wtd \% } \\
\text { Cover } \\
\text { region }\end{array}$ & \\
\hline TL & 12.86 & 0.26 & 39.41 & 1.58 & 17.87 & 5.90 & 27.90 & 6.42 & 5.89 & 2.06 & 12.56 & 0.25 & 16.46 \\
\hline DTLB & 0.00 & 0.00 & 48.42 & 1.94 & 47.29 & 15.61 & 16.48 & 3.79 & 33.55 & 11.74 & 0.00 & 0.00 & 33.08 \\
\hline TTP & 17.73 & 0.35 & 9.20 & 0.37 & 11.87 & 3.92 & 4.79 & 1.10 & 4.12 & 1.44 & 0.00 & 0.00 & 7.18 \\
\hline AV/TV & 0.00 & 0.00 & 0.00 & 0.00 & 2.75 & 0.91 & 0.93 & 0.21 & 14.03 & 4.91 & 0.00 & 0.00 & 6.03 \\
\hline DP & 0.00 & 0.00 & 0.00 & 0.00 & 0.24 & 0.08 & 0.30 & 0.07 & 0.00 & 0.00 & 0.00 & 0.00 & 0.15 \\
\hline BS & 0.00 & 0.00 & 0.16 & 0.01 & 1.02 & 0.34 & 0.33 & 0.08 & 0.47 & 0.16 & 0.79 & 0.02 & 0.60 \\
\hline $\mathbf{F P}$ & 5.96 & 0.12 & 0.00 & 0.00 & 0.00 & 0.00 & 0.00 & 0.00 & 0.00 & 0.00 & 0.00 & 0.00 & 0.12 \\
\hline RTS & 0.00 & 0.00 & 0.00 & 0.00 & 0.00 & 0.00 & 0.00 & 0.00 & 0.00 & 0.00 & 0.22 & 0.00 & 0.00 \\
\hline $\begin{array}{l}\text { Total tk } \\
(\%)\end{array}$ & 36.55 & & 97.19 & & 81.04 & & 50.73 & & 58.06 & & 13.57 & & 63.26 \\
\hline $\begin{array}{l}\text { Total no tk } \\
\text { Cover }(\%)\end{array}$ & 63.45 & & 2.81 & & 18.96 & & 49.27 & & 41.94 & & 86.43 & & 36.74 \\
\hline
\end{tabular}


Table 4

901 Spatial statistics for each type of landform across the entire study area and within each type of 902 surficial geology, (abbreviations as in Table 3)

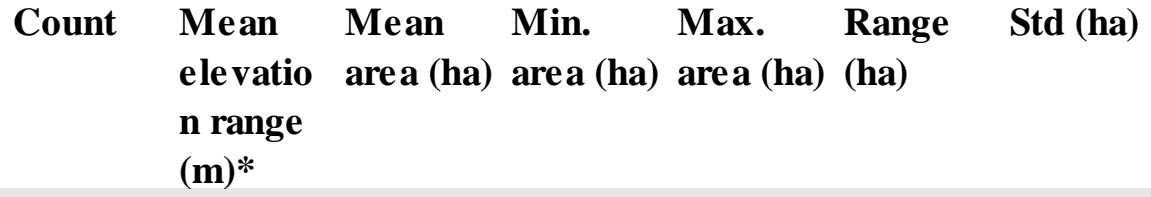

Entire study area

$\begin{array}{llllllll}\text { TL } & 212 & 6.36 & 24.33 & 0.09 & 8.00 & 559.03 & 63.52 \\ \text { DTLB } & 168 & 6.93 & 61.69 & 0.02 & 864.32 & 864.31 & 108.29 \\ \text { TTP } & 887 & - & 3.14 & 0.00 & 230.04 & 230.04 & 14.17 \\ \text { AV/TV } & 88 & 8.97 & 11.89 & 0.00 & 77.65 & 77.64 & 14.03 \\ \text { DP } & 110 & 2.64 & 1.04 & 0.00 & 11.39 & 11.39 & 1.93 \\ \text { BS } & 37 & 10.67 & 4.80 & 0.08 & 26.53 & 26.45 & 6.37 \\ \text { RTS } & 2 & & 2.77 & 1.37 & 4.18 & 2.81 & 1.99 \\ \text { FP } & 24 & & 2.69 & 0.32 & 10.73 & 10.41 & 2.33\end{array}$

Total \# 1528 (Currently active $=1358$, Currently inactive $=170$ )

Deltaic sands and gravels

$\begin{array}{llllllll}\text { TL } & 35 & 4.74 & 8.08 & 1.17 & 105.30 & 104.13 & 17.87 \\ \text { DTLB } & 0 & - & 0.00 & 0.00 & 0.00 & 0.00 & 0.00 \\ \text { TTP } & 111 & - & 3.69 & 0.00 & 62.25 & 62.25 & 7.77 \\ \text { TV } & 0 & - & 0.00 & 0.00 & 0.00 & 0.00 & 0.00 \\ \text { DP } & 20 & - & 3.32 & 0.08 & 11.39 & 11.30 & 3.40 \\ \text { BS } & 0 & - & 0.00 & 0.00 & 0.00 & 0.00 & 0.00 \\ \text { FP } & 24 & - & 2.69 & 0.32 & 10.73 & 10.41 & 2.33\end{array}$

Total \# 190 (Currently active=170, Currently inactive=20)

$\begin{array}{lrllllll}\text { Marine } & \text { silt } & & & & & \\ \text { TL } & 9 & 3.53 & 109.92 & 1.51 & 559.12 & 557.61 & 188.23 \\ \text { DTLB } & 8 & 5.30 & 232.24 & 4.20 & 864.32 & 860.12 & 304.00 \\ \text { TTP } & 1 & - & 230.04 & 230.04 & 230.04 & 0.00 & 0.00 \\ \text { TV } & 0 & - & 0.00 & 0.00 & 0.00 & 0.00 & 0.00 \\ \text { DP } & 0 & - & 0.00 & 0.00 & 0.00 & 0.00 & 0.00 \\ \text { BS } & 1 & 2.51 & 4.69 & 4.69 & 4.69 & 0.00 & 0.00\end{array}$

Total \# 19 (Currently active $=11$, Currently inactive $=8$ )

\section{Marine sand}

$\begin{array}{llllllll}\text { TL } & 54 & 2.54 & 33.09 & 0.11 & 488.13 & 488.03 & 81.98 \\ \text { DTLB } & 72 & 5.01 & 58.89 & 0.29 & 635.03 & 634.74 & 101.52 \\ \text { TTP } & 266 & - & 4.50 & 0.00 & 181.03 & 181.03 & 15.34 \\ \text { TV } & 15 & 6.07 & 18.35 & 3.84 & 77.65 & 73.81 & 18.46 \\ \text { DP } & 55 & 1.67 & 0.36 & 0.00 & 4.10 & 4.10 & 0.56 \\ \text { BS } & 10 & 8.08 & 11.57 & 1.29 & 26.53 & 25.23 & 9.35\end{array}$


Count Mean Mean Min. Max. Range Std (ha) elevatio area (ha) area (ha) area (ha) (ha) n range

(m)*

$\begin{array}{llllllll}\text { Aolian sand } & & & & & & & \\ \text { TL } & 55.00 & 7.00 & 37.80 & 0.44 & 245.25 & 244.81 & 54.55 \\ \text { DTLB } & 65.00 & 8.87 & 37.26 & 0.02 & 239.17 & 239.15 & 46.26 \\ \text { TTP } & 168.00 & - & 1.86 & 0.00 & 24.67 & 24.66 & 3.23 \\ \text { TV } & 14.00 & 7.25 & 4.96 & 0.45 & 18.66 & 18.21 & 4.87 \\ \text { DP } & 35.00 & 2.36 & 0.64 & 0.04 & 4.06 & 4.02 & 0.74 \\ \text { BS } & 10.00 & 10.31 & 2.79 & 0.08 & 4.96 & 4.88 & 1.93\end{array}$

Total \# 347 (Currently active=247, Currently inactive $=100$ )

$\begin{array}{llllllll}\text { Aolian silt } & & & & & & & \\ \text { TL } & 24.00 & 11.00 & 12.27 & 1.17 & 78.03 & 76.86 & 20.13 \\ \text { DTLB } & 23.00 & 19.26 & 80.22 & 1.01 & 321.05 & 320.04 & 86.02 \\ \text { TTP } & 341.00 & - & 1.21 & 0.00 & 59.48 & 59.48 & 5.68 \\ \text { AV } & 59.00 & 17.46 & 11.89 & 0.00 & 62.27 & 62.26 & 13.62 \\ \text { DP } & 0.00 & - & 0.00 & 0.00 & 0.00 & 0.00 & 0.00 \\ \text { BS } & 4.00 & 14.19 & 6.60 & 1.26 & 13.82 & 12.55 & 5.25\end{array}$

Total \# 451 (Currently active=428, Currently inactive $=23$ )

\section{Glacial drift and till}

$\begin{array}{llllllll}\text { TL } & 35.00 & 13.69 & 8.77 & 1.08 & 130.99 & 130.90 & 22.23 \\ \text { DTLB } & 0.00 & - & 0.00 & 0.00 & 0.00 & 0.00 & 0.00 \\ \text { TTP } & 0.00 & - & 0.00 & 0.00 & 0.00 & 0.00 & 0.00 \\ \text { TV } & 0.00 & - & 0.00 & 0.00 & 0.00 & 0.00 & 0.00 \\ \text { DP } & 0.00 & - & 0.00 & 0.00 & 0.00 & 0.00 & 0.00 \\ \text { BS } & 12.00 & 13.19 & 1.86 & 0.17 & 8.08 & 7.91 & 2.16 \\ \text { RTS } & 2.00 & - & 2.77 & 1.37 & 4.18 & 2.81 & 1.99\end{array}$

904 Total \# 49 (Currently active $=47$, Currently inactive $=2$ )

905

906

907

908

909

910

911 


\section{Appendices A}

\section{Table A.1.}

915 Study area metadata

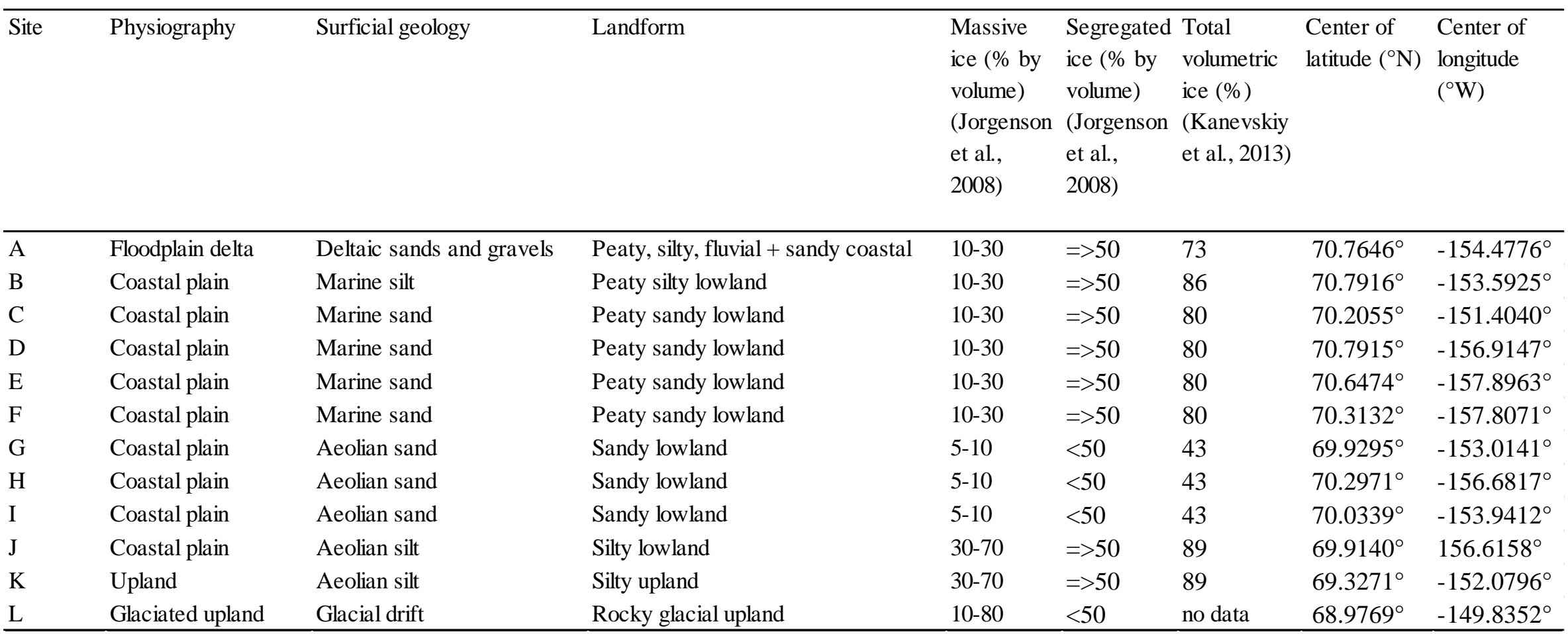




\section{Table A.2.}

919 Locations of permafrost boreholes used in this study.

\begin{tabular}{lcl}
\hline Site & Latitude N & Longitude \\
\hline Galbraith & $68.479717^{\circ}$ & $-149.488767^{\circ}$ \\
Inigok & $69.989617^{\circ}$ & $-153.093833^{\circ}$ \\
Umiat & $69.395683^{\circ}$ & $-152.142800^{\circ}$ \\
Koluktak & $69.751600^{\circ}$ & $-154.617567^{\circ}$ \\
Fish Creek & $70.335233^{\circ}$ & $-152.052000^{\circ}$ \\
South Meade & $70.628467^{\circ}$ & $-156.835317^{\circ}$ \\
Drew Point & $70.864509^{\circ}$ & $-153.906745^{\circ}$ \\
\hline
\end{tabular}

920

921

922 


\section{Table A.3.}

930 Slope statistics for each surficial geology region calculated using the Scenarios Network for Alaska (SNAP) $1 \mathrm{~km}$ resolution Alaska slope

931 model (http://ckan.snap.uaf.edu/dataset/slope).

\begin{tabular}{|c|c|c|c|c|c|c|}
\hline & \multicolumn{3}{|c|}{ Regional slope $\left(^{\circ}\right)$} & \multicolumn{3}{|c|}{ Mapped area slope $\left(^{\circ}\right)$} \\
\hline & Mean & Min & $\operatorname{Max}$ & Mean & Min & $\operatorname{Max}$ \\
\hline Marine sand & 0.10 & 0.00 & 1.24 & 0.06 & 0.01 & 0.12 \\
\hline Marine silt & 0.03 & 0.00 & 0.11 & 0.04 & 0.02 & 0.06 \\
\hline Aeolian sand & 0.10 & 0.00 & 0.71 & 0.06 & 0.01 & 0.14 \\
\hline Aeolian silt & 0.32 & 0.00 & 1.80 & 0.27 & 0.05 & 0.70 \\
\hline Deltaic sands and gravels & 0.04 & 0.00 & 0.21 & 0.01 & 0.00 & 0.02 \\
\hline Glacial drift & 2.04 & 0.00 & 12.57 & 0.81 & 0.17 & 1.36 \\
\hline
\end{tabular}




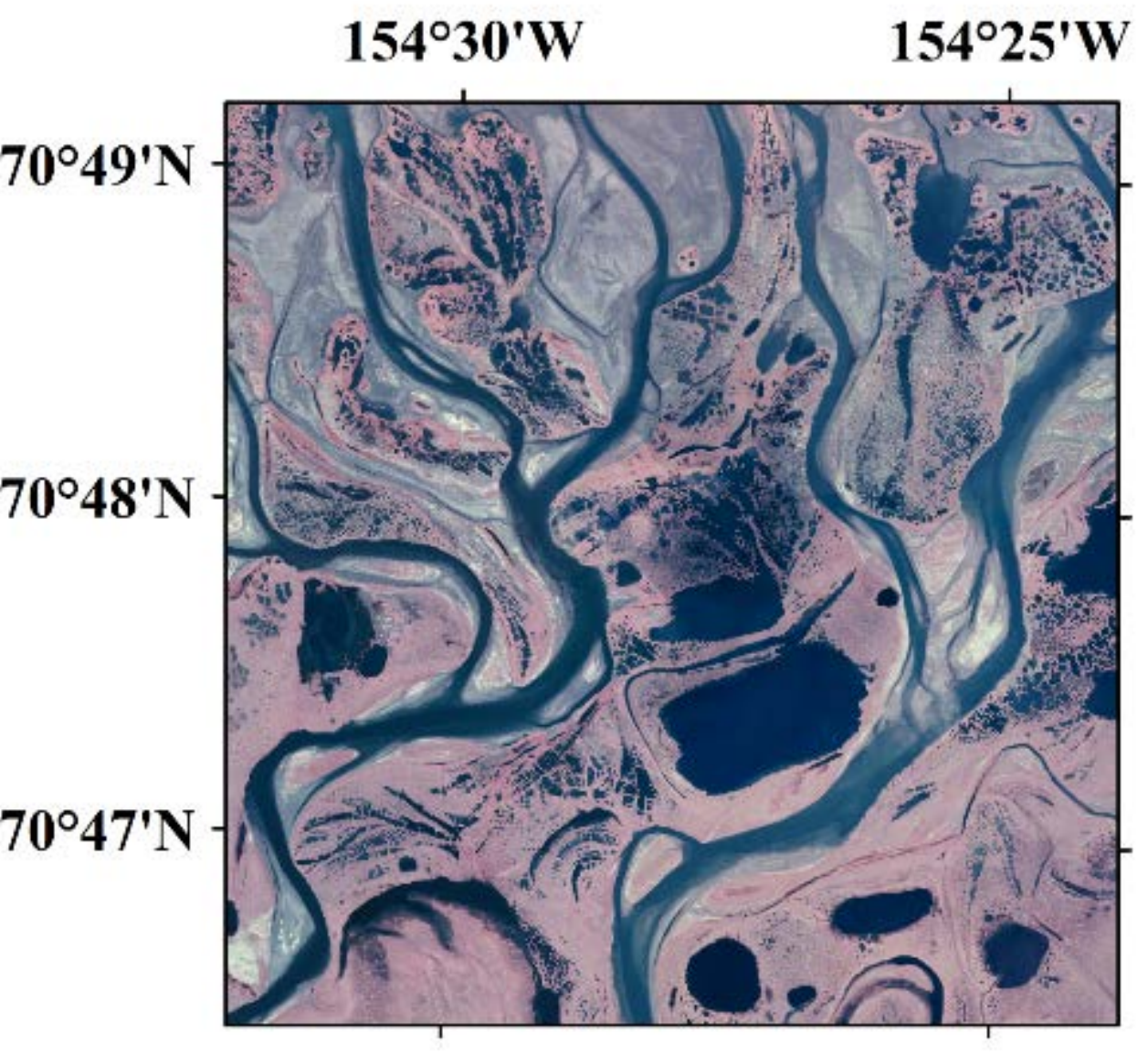

936 


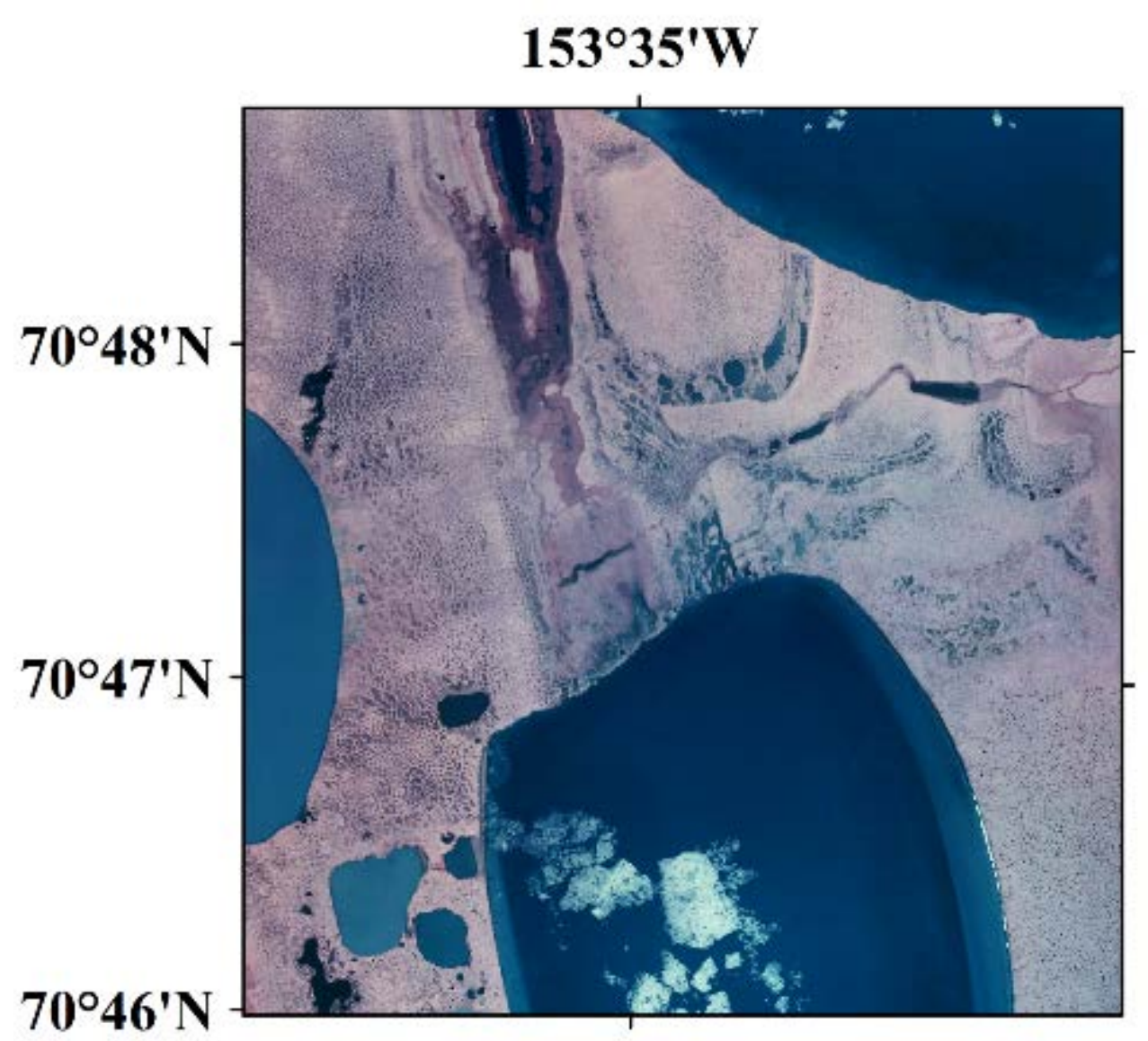

940 Fig. B.2. Study area B 


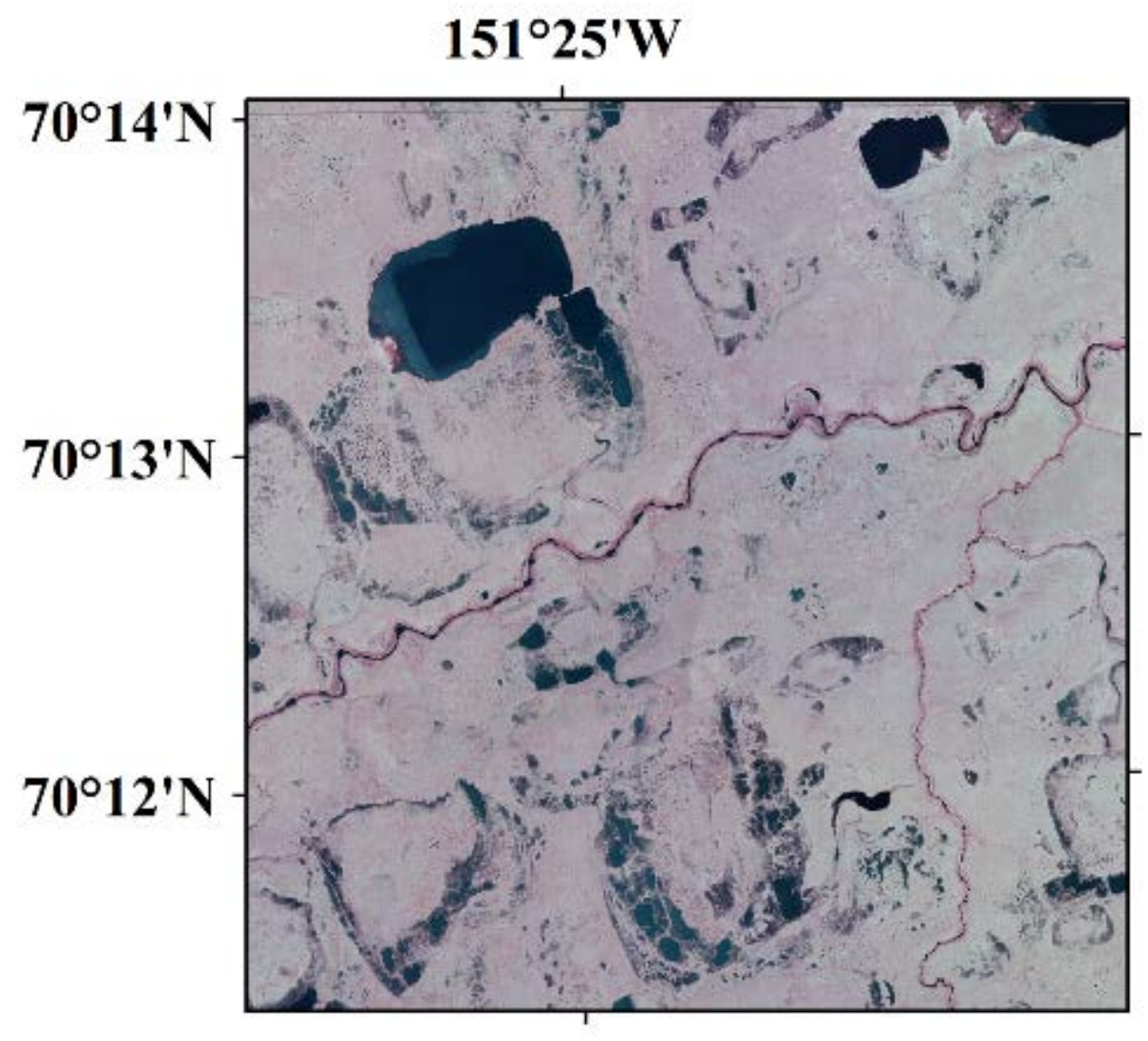

941

Fig. B.3. Study area C 


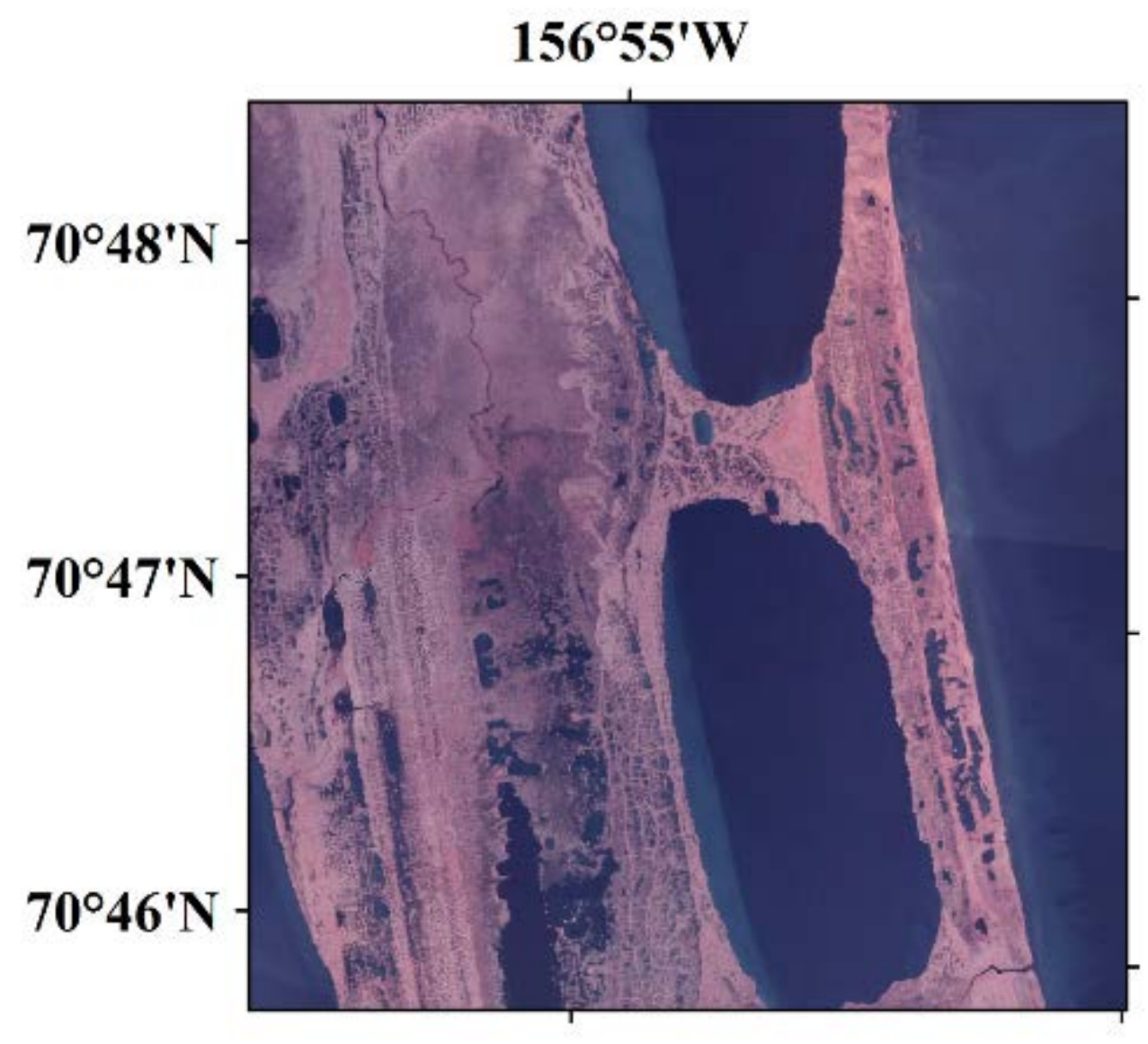

Fig. B.4. Study area D 


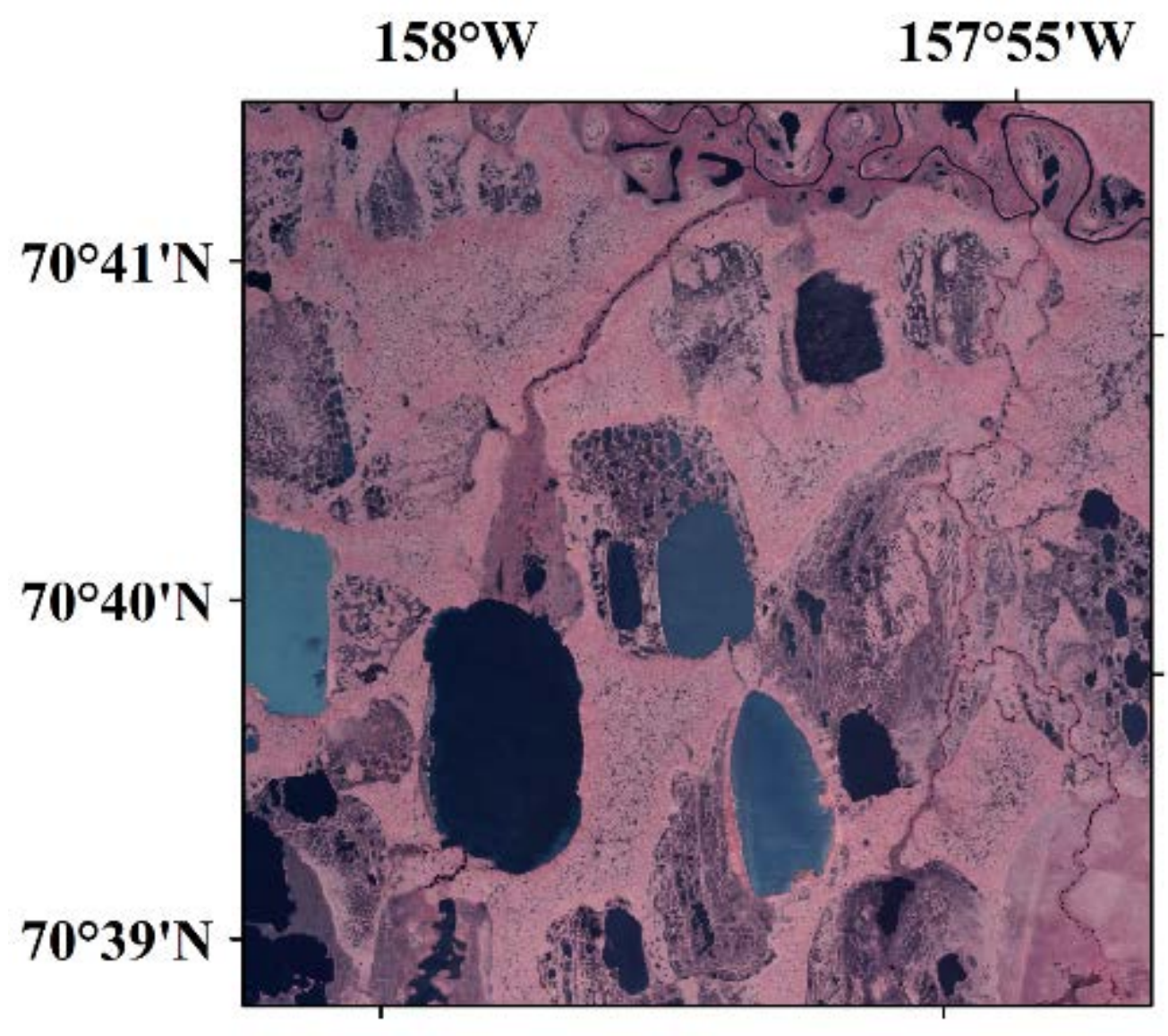

946 Fig. B.5. Study area E 


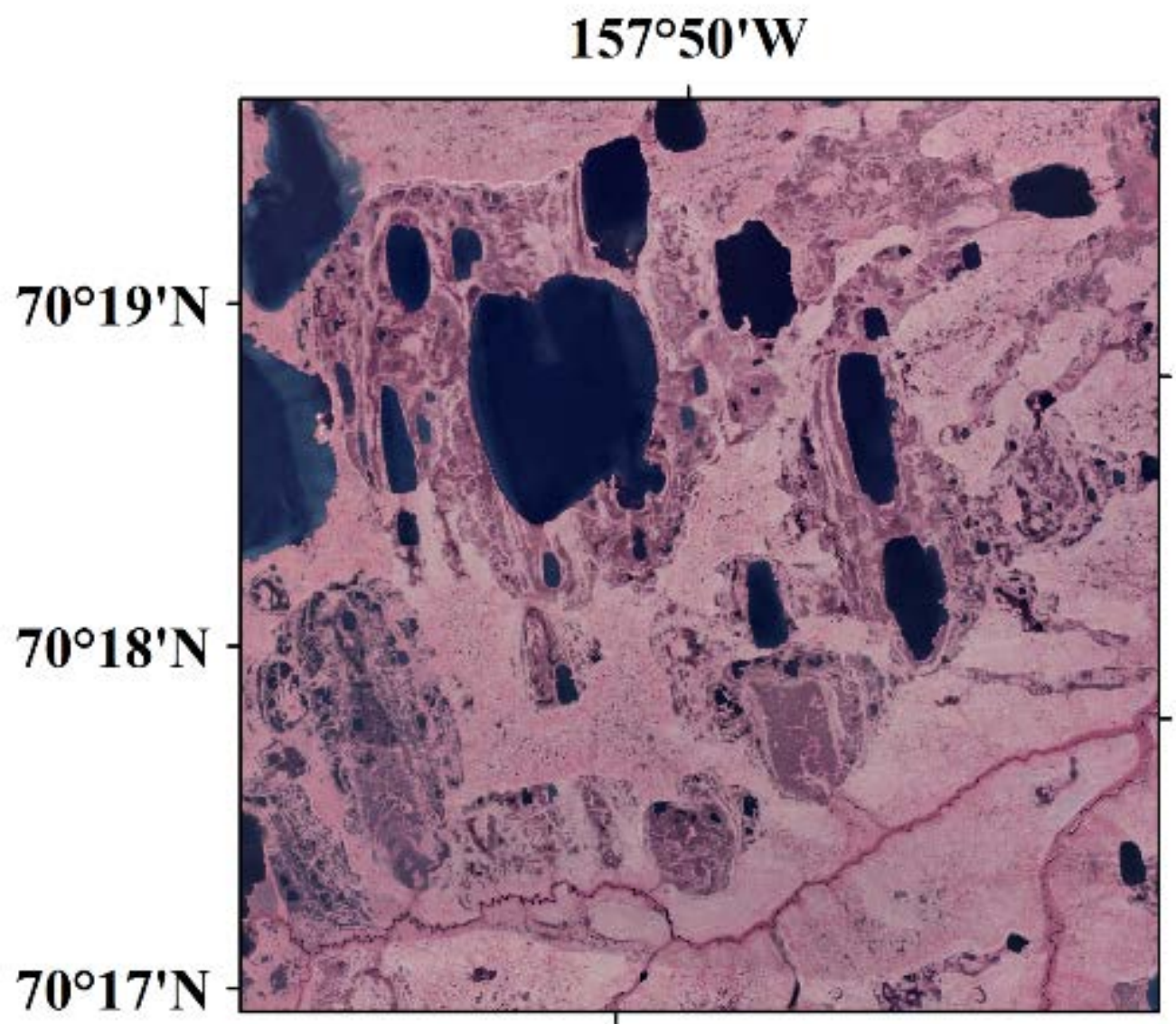

Fig. B.6. Study area F 


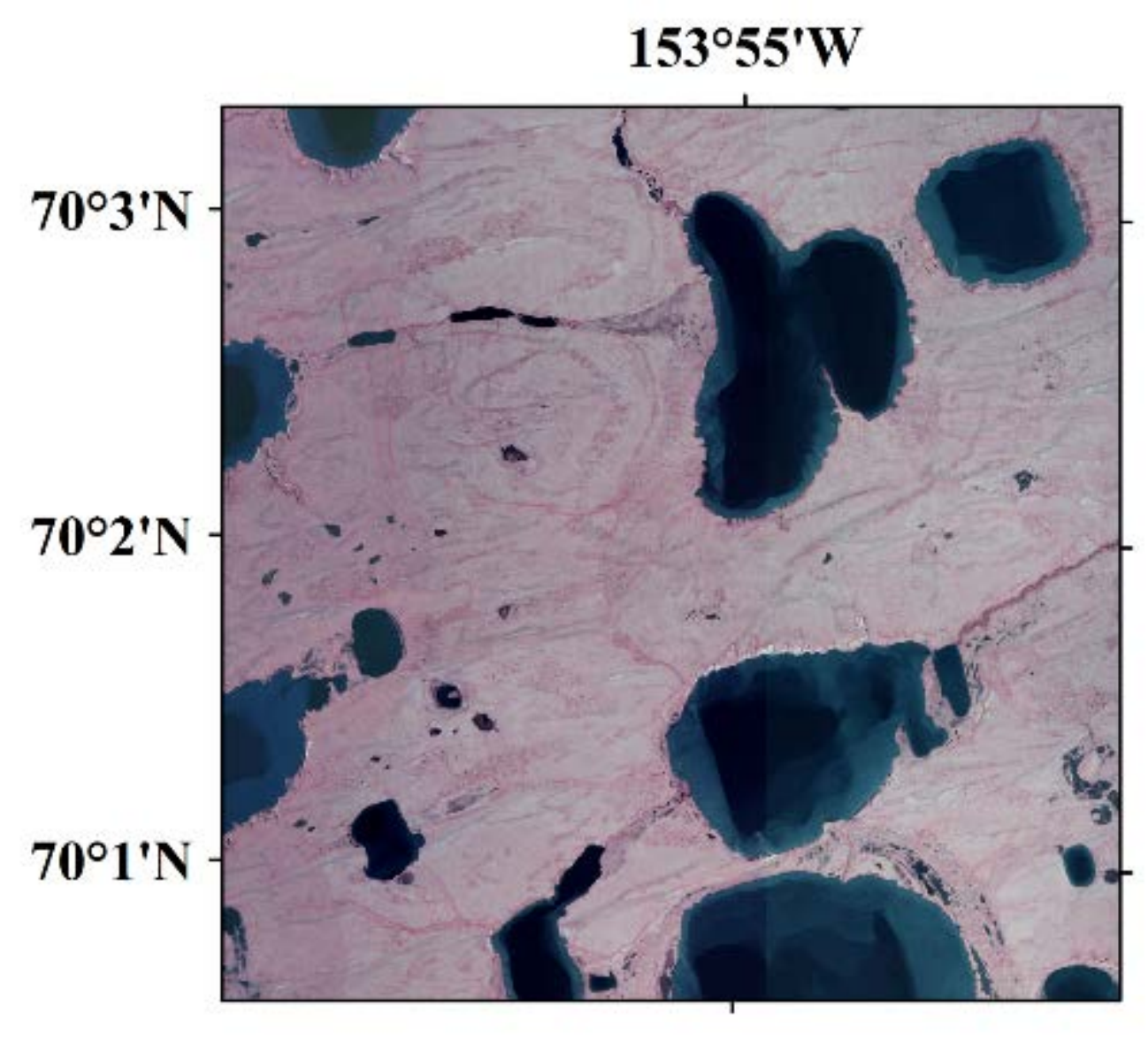

949

950

Fig. B.7. Study area G 


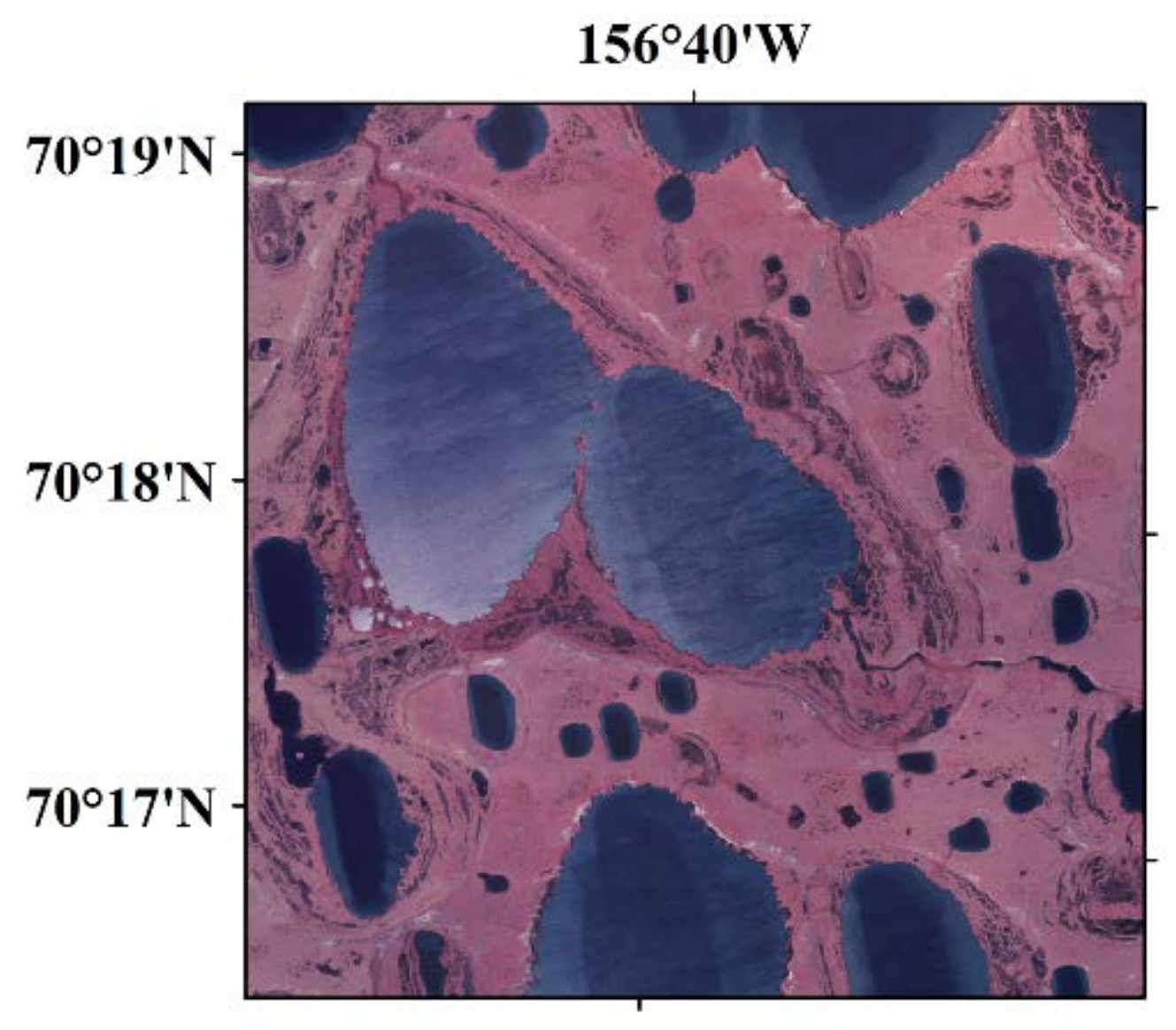

951

952 Fig. B.8. Study area H 


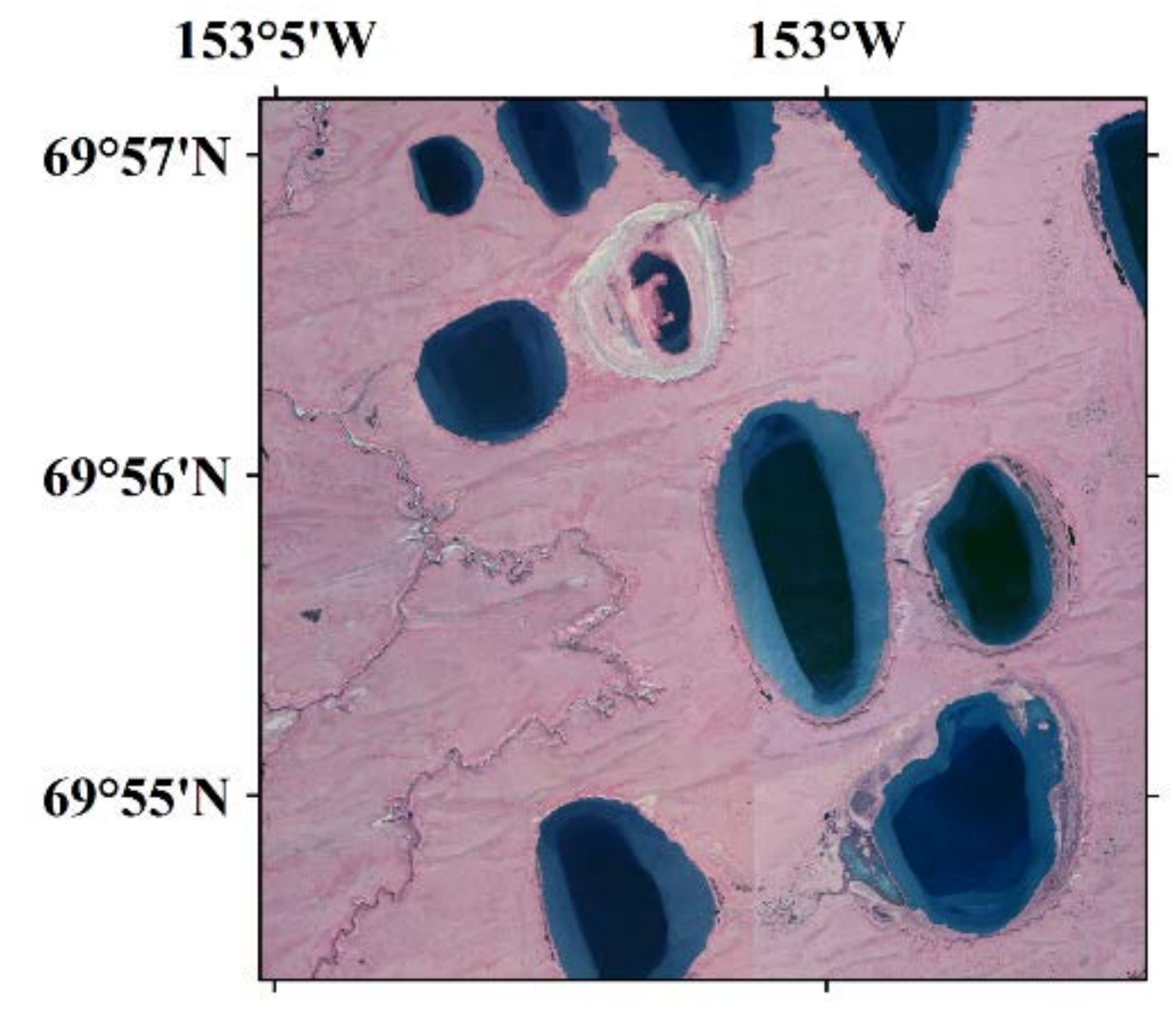

953

Fig. B.9. Study area I 


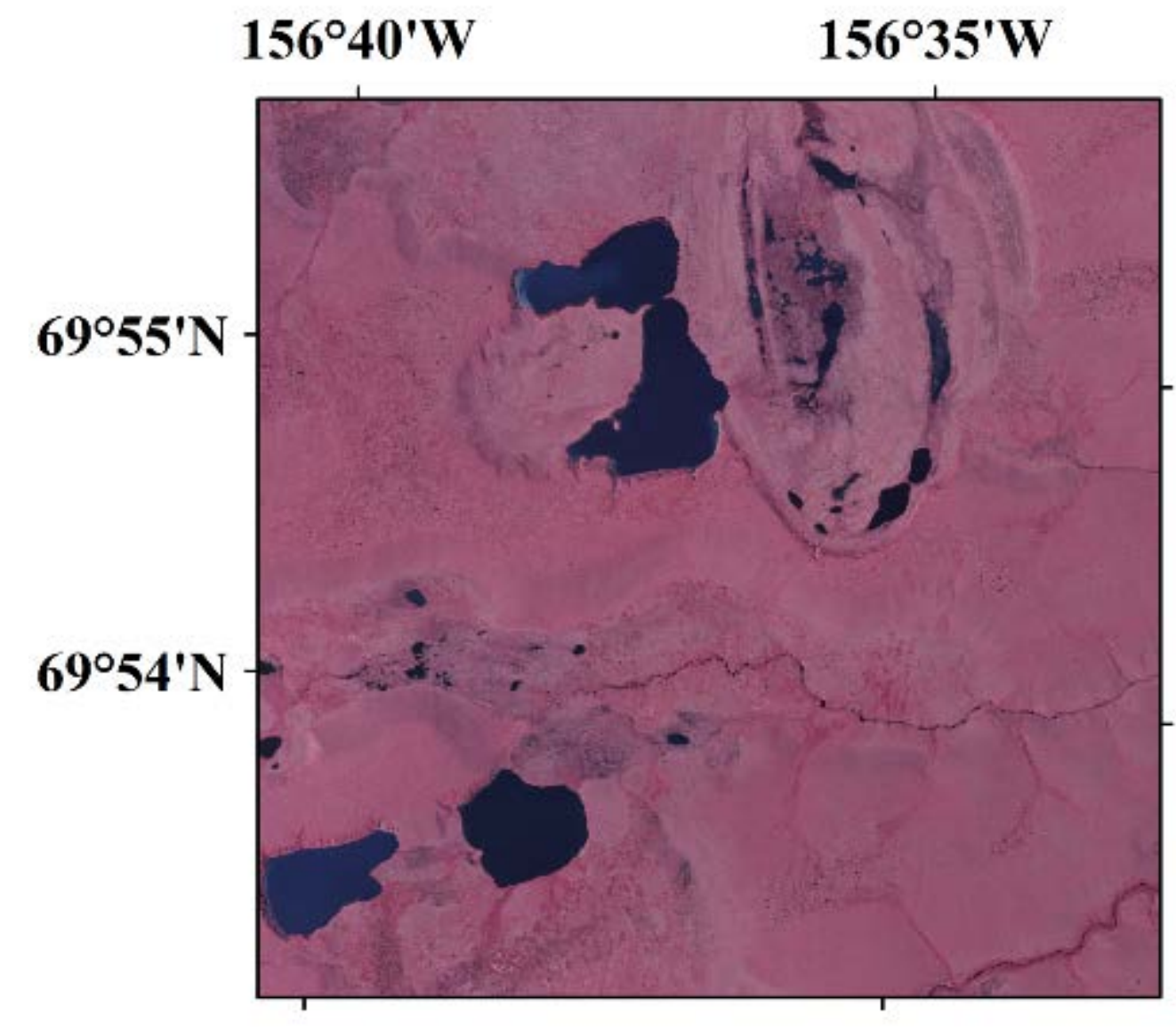

Fig. B.10. Study area J 


\section{$152^{\circ} 10^{\prime} \mathrm{W}$}

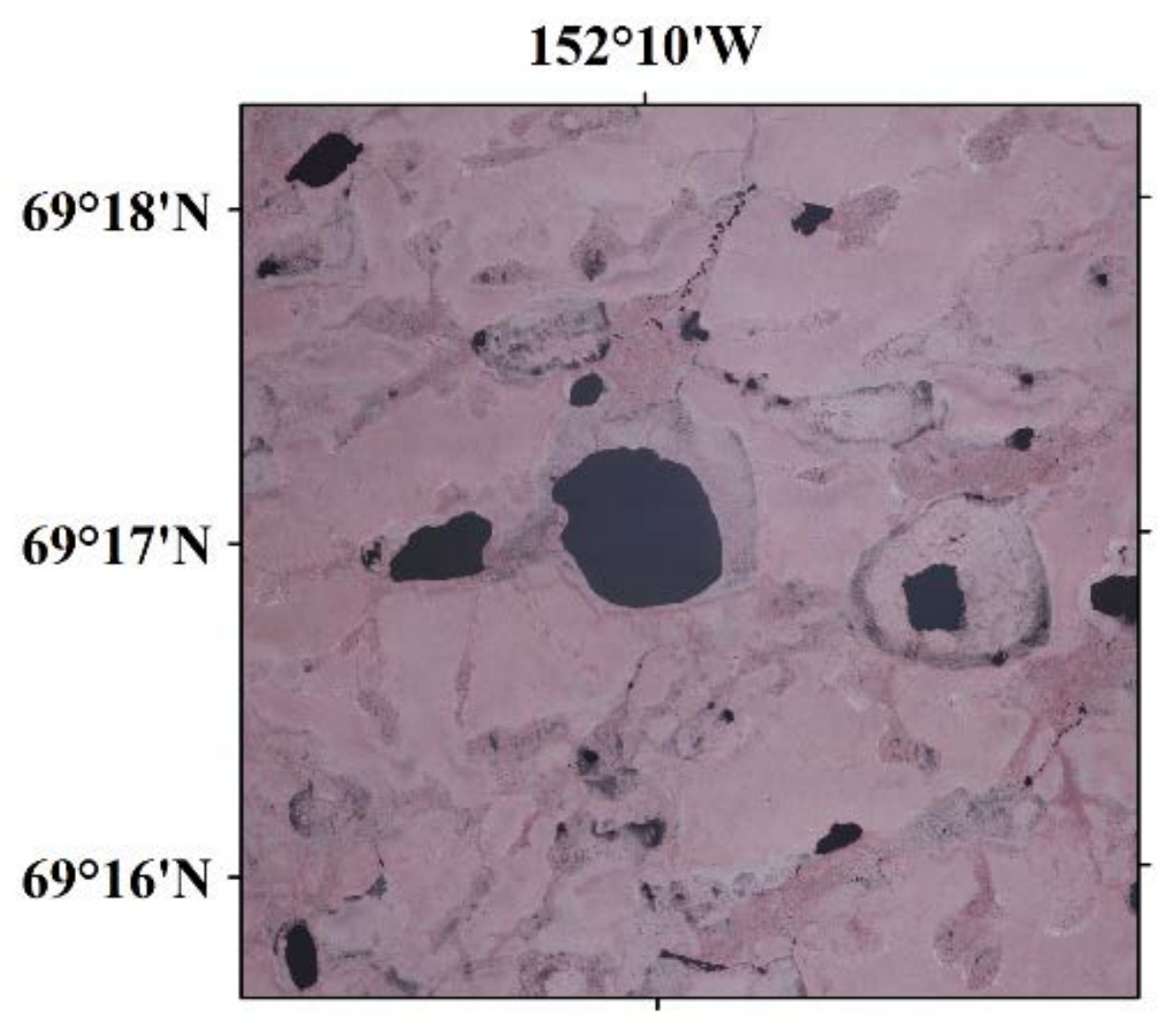

958 Fig. B.11. Study area K 


\section{$149^{\circ} 40^{\prime} \mathrm{W}$}

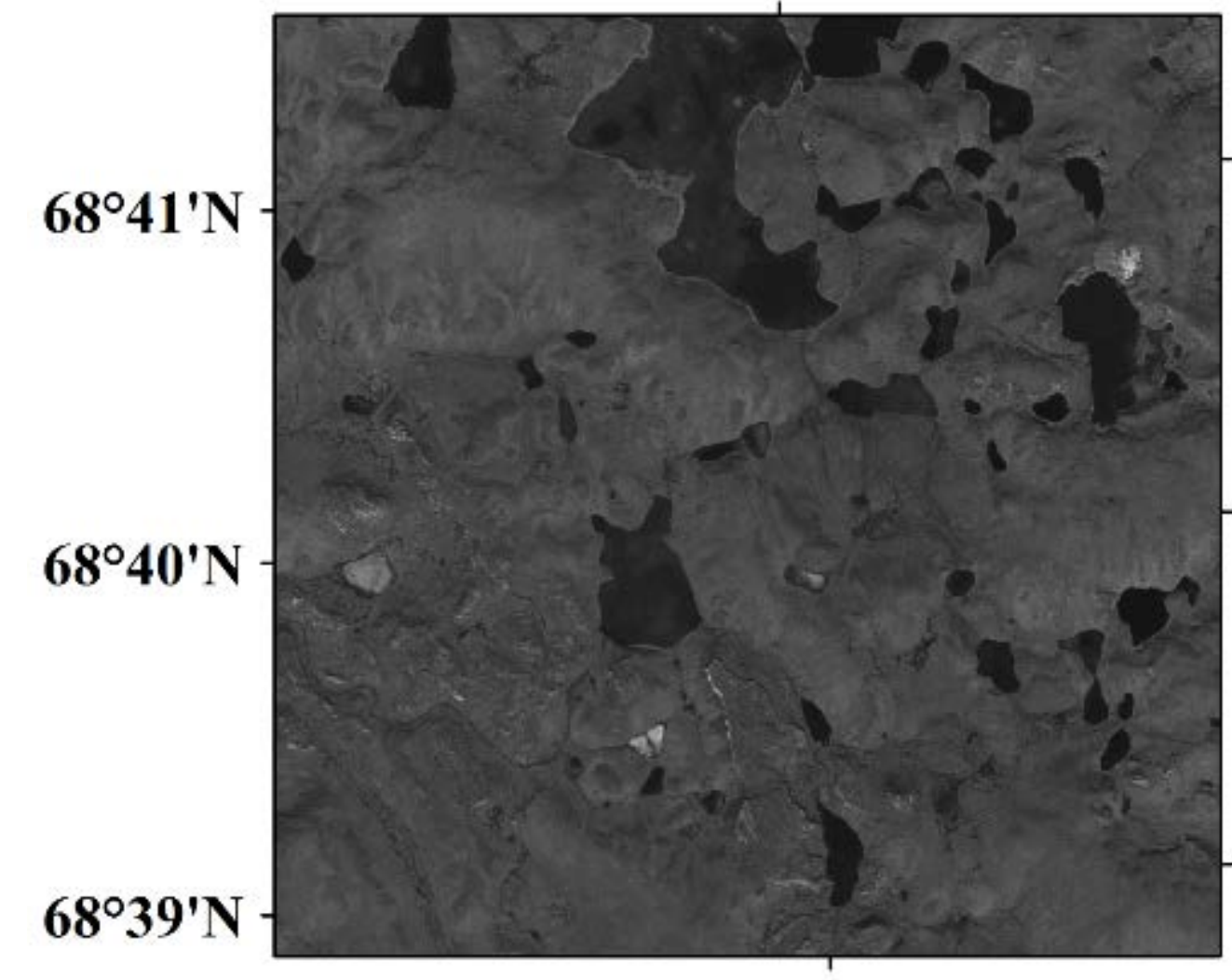

96

Fig. B.12. Study area L

961

962 